\title{
The global impact of the transport sectors on atmospheric aerosol in 2030 - Part 1: Land transport and shipping
}

\author{
M. Righi, J. Hendricks, and R. Sausen \\ Deutsches Zentrum für Luft- und Raumfahrt (DLR), Institut für Physik der Atmosphäre, Oberpfaffenhofen, Germany \\ Correspondence to: M. Righi (mattia.righi@dlr.de)
}

Received: 5 August 2014 - Published in Atmos. Chem. Phys. Discuss.: 8 September 2014

Revised: 1 December 2014 - Accepted: 7 December 2014 - Published: 19 January 2015

\begin{abstract}
Using the EMAC (ECHAM/MESSy Atmospheric Chemistry) global climate-chemistry model coupled to the aerosol module MADE (Modal Aerosol Dynamics model for Europe, adapted for global applications), we simulate the impact of land transport and shipping emissions on global atmospheric aerosol and climate in 2030. Future emissions of short-lived gas and aerosol species follow the four Representative Concentration Pathways (RCPs) designed in support of the Fifth Assessment Report of the Intergovernmental Panel on Climate Change. We compare the resulting 2030 land-transport- and shipping-induced aerosol concentrations to the ones obtained for the year 2000 in a previous study with the same model configuration. The simulations suggest that black carbon and aerosol nitrate are the most relevant pollutants from land transport in 2000 and 2030 and their impacts are characterized by very strong regional variations during this time period. Europe and North America experience a decrease in the land-transport-induced particle pollution, although in these regions this sector remains a major source of surface-level pollution in 2030 under all RCPs. In Southeast Asia, however, a significant increase is simulated, but in this region the surface-level pollution is still controlled by other sources than land transport. Shipping-induced air pollution is mostly due to aerosol sulfate and nitrate, which show opposite trends towards 2030. Sulfate is strongly reduced as a consequence of sulfur reduction policies in ship fuels in force since 2010, while nitrate tends to increase due to the excess of ammonia following the reduction in ammonium sulfate. The aerosol-induced climate impact of both sectors is dominated by aerosol-cloud effects and is projected to decrease between 2000 and 2030, nevertheless still contributing a significant radiative forcing to Earth's radiation budget.
\end{abstract}

\section{Introduction}

The transport sectors, including land transport, shipping and aviation, are major sources of atmospheric pollution (e.g., Righi et al., 2013). The emissions from transport are growing more rapidly than those from the other anthropogenic activities. According to the ATTICA assessment (Uherek et al., 2010; Eyring et al., 2010), land transport and shipping shared 74 and $12 \%$ of the global $\mathrm{CO}_{2}$ emissions from transport in the year 2000, respectively. In the time period 1990-2007, the EU-15 $\mathrm{CO}_{2}$-equivalent emissions from land transport and shipping increased by 24 and $63 \%$, respectively. This growth is expected to continue in the future, due to increasing world population, economic activities and related mobility. The future road traffic scenarios analyzed by Uherek et al. (2010) essentially agree in projecting an increase of both fuel demand and $\mathrm{CO}_{2}$ emissions until 2030, with up to a factor of $\sim 3$ increase in $\mathrm{CO}_{2}$ emissions with respect to 2000 . The ATTICA assessment also showed that emissions of $\mathrm{CO}_{2}$ from land transport and shipping affect the global climate by exerting a radiative forcing (RF) effect of 171 (year 2000) and $37 \mathrm{~mW} \mathrm{~m}^{-2}$ (year 2005), respectively. These two sectors together account for $13 \%$ of the total anthropogenic $\mathrm{CO}_{2}$ warming (year 2005).

In addition to long-lived greenhouse gases, ground-based vehicles and ocean-going ships emit aerosol particles as well as a wide range of short-lived gases, including also aerosol precursor species. Atmospheric aerosol particles have significant impacts on climate, through their interaction with solar radiation and their ability to modify cloud microphysical and optical properties (Forster et al., 2007). In populated areas, they also affect air quality and human health (Pope and Dockery, 2006; Chow et al., 2006). 
The present work represents a follow-up study of Righi et al. (2013, hereafter R13). In that study, we considered year 2000 emissions and performed several sets of model simulations (i) to estimate transport impacts on atmospheric aerosol, (ii) to quantify the uncertainty in the effects on particle number concentrations related to the assumed particle size distribution of emitted particles, (iii) to explore nonlinearities in the aerosol response to the perturbations induced by transport emissions; and (iv) to quantify the radiative forcings of transport-induced aerosol. These model experiments revealed that land transport is the most significant source of large-scale particulate matter pollution (mostly black carbon and nitrate) in Europe, the USA and the Arabian Peninsula, while it is less relevant in southern and eastern Asia, where other sources dominate. The impact of the shipping sector was found to be of high importance over the oceans in the Northern Hemisphere, especially for sulfate and nitrate aerosol, with significant effects also along the coastlines. The transport-induced changes of aerosol number concentration turned out to be very sensitive to the assumed size distribution of emitted particles, with the largest uncertainty (spanning about 1 order of magnitude) simulated for the land transport sector. We found that the aerosol response to the emission perturbations is approximately linear for black carbon, particulate organic matter and particle number. In contrast, nonlinearities were found for aerosol nitrate, sulfate and ammonium, due to the nonlinear behavior of the chemical processes involved in the formation of these species.

The aerosol impacts on Earth's radiation budget induced by the transport sources were estimated in R13, in terms of all-sky and clear-sky global RF. For each sector, a range of possible RF values was calculated, according to the different assumptions on the size distributions of emitted particles. For land transport and shipping, we simulated ranges of -80 to $-12 \mathrm{~mW} \mathrm{~m}^{-2}$ and of -222 to $-153 \mathrm{~mW} \mathrm{~m}^{-2}$, respectively, with a dominant contribution from cloud effects in both cases.

The present study complements R13 by presenting the impacts of land transport and shipping for different future scenarios. The impact of aviation emissions will be the subject of a companion study. In particular, we focus here on the year 2030 emissions based on the four Representative Concentration Pathways (RCPs; Moss et al., 2010; van Vuuren et al., 2011a). These scenarios were developed in support of the Fifth Assessment Report of the Intergovernmental Panel on Climate Change (IPCC AR5). We choose the year 2030 in order to reduce the influence of the uncertainties in the emission data, as such uncertainties are known to increase with the projection time. In analogy to R13, we focus only on the effects of the emission of aerosol and aerosol precursors, while we refrain from considering the impact of climate change on aerosol distributions. This enables us to quantify the pure effect of emission changes on aerosol when comparing the 2030 simulations with the year 2000 experiments by $\mathrm{R} 13$. The model therefore is driven by prescribed concentra- tions of long-lived species and radiatively active gases representative of year 2000 conditions, and by meteorological data for the period 1996-2005 to nudge the dynamics, although the impact of a changing climate on aerosol distribution (via, for example, changes in precipitation and wind patterns, and in surface temperature, affecting deposition and gas-phase reaction rates) could be important (Pye et al., 2009; Kloster et al., 2009; Megaritis et al., 2013). This investigation, however, is beyond the scope of the present study.

We use the EMAC (ECHAM/MESSy Atmospheric Chemistry) global climate-chemistry model with the aerosol module MADE (Modal Aerosol Dynamics model for Europe, adapted for global applications). The model is able to track both aerosol mass and number concentrations, and to simulate the aerosol-cloud and aerosol-radiation interactions, hence allowing the estimation of aerosol RF effects. In addition to the global effects, we also focus on specific regions, where land transport and shipping emissions are expected to change significantly compared to 2000, following the changes in transport activity and the implementation of various mitigation strategies and pollution-control measures.

Several recent studies dealt with aerosol distributions and related climate impacts under the RCPs. Chalmers et al. (2012) investigated the near-term (up to 2050) climate effect of aerosol in two RCP scenarios (RCP2.6 and RCP4.5, corresponding to global RFs of 2.6 and $4.5 \mathrm{~W} \mathrm{~m}^{-2}$ in 2100 , respectively; see Sect. 3 for more details). They found a larger near-term net warming in RCP2.6 than in RCP4.5 even though the warming due to greenhouse gases is smaller in RCP2.6: this is due to a strong reduction in sulfur emissions and the resulting reduction in aerosol-induced cooling in RCP2.6. They also stress the key role of aerosol emissions in the quantification of near-term climate impacts. The review by Fiore et al. (2012) presented regional projections of particulate matter $\left(\mathrm{PM}_{2.5}\right.$, i.e., particles with diameter smaller than $2.5 \mu \mathrm{m}$ ) across the 21 st century, supported by the Atmospheric Chemistry Climate Intercomparison Project (ACCMIP; Lamarque et al., 2013) and the Coupled Model Intercomparison Project Phase 5 (CMIP5; Taylor et al., 2012) multimodel studies. They found an overall decline in $\mathrm{PM}_{2.5}$ concentration for all RCPs scenarios, which does not follow the RCPs RF and $\mathrm{CO}_{2}$ pathways: the model simulations showed that RCP6.0 and RCP4.5 represent the high and low ends of the $\mathrm{PM}_{2.5}$ range, respectively, whereas they are in the medium range of the climate projections. Takemura (2012) analyzed the aerosol evolution along the RCPs using the SPRINTARS (Spectral Radiation-Transport Model for Aerosol Species) model and found that the aerosol load is decreasing in Europe and North America, while it is still increasing in Asia due to economic growth and is expected to peak by 2050 . The climate impact of aerosol was found to match the time evolution of loads, leading to reduced aerosol cooling by the end of the century and causing accelerated global warming. This further motivates the necessity of exploring the aerosol impacts from different sources in 
the RCPs, given that the response of short-lived species appears to be completely different from the projected changes in long-lived species and anthropogenic net RF in these scenarios. Transport-related sources are of particular relevance in this context, due to their comparatively large growth rates.

The present work adds a detailed analysis of the effects of the emissions from surface-based transport sources on aerosol and climate under the four RCPs to the abovementioned studies. Our paper is organized as follows: the EMAC model (including the aerosol module MADE) is briefly explained in Sect. 2 (while we refer to R13 for a more detailed description). The RCP scenarios and the trends in transport-related emissions are described in Sect. 3. The impacts of land transport and shipping on aerosol surface-level concentrations and their changes between 2000 and 2030 are presented in Sect. 4. We discuss the climate impacts resulting from transport emissions in Sect. 5 and present our conclusions in Sect. 6.

\section{Model and simulations}

We apply the aerosol module MADE (Lauer et al., 2005, 2007) coupled to the EMAC model (Roeckner et al., 2006; Jöckel et al., 2006). A detailed description of the EMACMADE system is provided in R13. Here we give just a short summary of its main features.

MADE considers 10 aerosol tracers: hydrophilic and hydrophobic black carbon (BC), hydrophilic and hydrophobic particulate organic matter (POM), aerosol sulfate $\left(\mathrm{SO}_{4}\right)$, nitrate $\left(\mathrm{NO}_{3}\right)$, ammonium $\left(\mathrm{NH}_{4}\right)$, mineral dust, sea salt and aerosol water. The aerosol population is described by considering three internally mixed log-normal modes (Aitken, accumulation and coarse mode) and taking into account microphysical processes such as nucleation, condensation (of sulfuric acid and organic compounds) and coagulation. Aging of hydrophobic to hydrophilic BC and POM is parameterized as an exponential decay, with an e-folding time of $24 \mathrm{~h}$. To improve the computational efficiency, simplified gas and liquid phase chemistry schemes are adopted for this study, considering basic tropospheric background reactions $\left(\mathrm{NO}_{\mathrm{x}}-\right.$ $\mathrm{HO}_{\mathrm{x}}-\mathrm{CH}_{4}-\mathrm{CO}-\mathrm{O}_{3}$ chemistry) and the sulfur cycle.

In order to estimate the aerosol effects on climate, MADE is coupled to the cloud and radiation schemes of EMAC. Aerosol activation and interactions with clouds follow the parameterization by Abdul-Razzak and Ghan (2000) and the two-moment cloud scheme by Lohmann et al. (1999) and Lohmann (2002). Aerosol optical properties are calculated based on the Mie theory and coupled to the radiation scheme of EMAC. As in R13, the radiation and gas phase chemistry schemes of the model are decoupled, in order to isolate the aerosol impact. This is attained by prescribing radiatively active gases (ozone, $\mathrm{CO}_{2}, \mathrm{CH}_{4}, \mathrm{~N}_{2} \mathrm{O}, \mathrm{CFC}-11$ and $\mathrm{CFC}-12$ ) by means of climatologies or constant values in the radiation calculations.
Note that, although the simulations of this paper consider 2030 emissions, the concentrations of radiatively active gases are prescribed using the same fields as R13, corresponding to year 2000 conditions, and the model dynamics (vorticity, divergence, temperature, and surface pressure) is nudged using the European Centre for Medium-Range Weather Forecast (ECMWF) operational analysis data over the 1996-2005 period. This might appear inconsistent but it is a necessary choice in order to distinguish the effects of the emission changes on aerosol and aerosol-induced climate forcing from the effects of climate change on atmospheric aerosol. As mentioned above, the latter effects are not covered in this work, but will be the subject of future investigations.

The adopted resolution is T42L19 for all experiments of this work, corresponding to a Gaussian latitude-longitude grid of about $2.8^{\circ} \times 2.8^{\circ}$, with 19 vertical hybrid $\sigma$-pressure levels from the surface to the top model layer, which is centered at $10 \mathrm{hPa}(\sim 30 \mathrm{~km})$. A detailed evaluation of EMACMADE was performed by Lauer et al. $(2005,2007)$ and Aquila et al. (2011), and also by R13 specifically for the regions where the impacts of the emissions from the transport sectors are known to be significant.

For each of the four RCP scenarios (2.6, 4.5, 6.0, and 8.5), we perform a reference experiment and a perturbation experiment, in which the emissions from land transport or shipping are switched off, resulting in a total of 12 simulations. The impacts of aerosol emission for each sector and scenario are then obtained as the difference between the reference experiment and the experiment with the emissions from the corresponding sector switched off. This method (also known as $100 \%$-perturbation method) and the resulting uncertainties related to nonlinearities in the aerosol response have been discussed in detail in R13.

\section{0 emissions in the Representative Concentration Pathways}

Beyond concentrations of long-lived greenhouse gases, the RCP scenarios (Moss et al., 2010; van Vuuren et al., 2011a) provide future projections of the emissions of short-lived species until 2100. The emission changes of air pollutants in the RCPs are calculated taking into account the changes in driving forces (fossil fuel and fertilizer consumption), combined with both air quality control policies and climate policies. The consideration of climate policies is one of the novelty aspects of the RCPs with respect to the previous SRES (Special Report on Emissions Scenarios; Nakicenovic et al., 2000). However, as indicated below, the projections of the emissions of short-lived species are questioned whether they display consistent futures.

The four RCPs are defined according to the projected RFs and $\mathrm{CO}_{2}$ concentrations in 2100 .

- RCP2.6 (van Vuuren et al., 2007, 2011b) follows a peak-and-decline (overshoot) pathway, characterized 
by a RF peak of $3 \mathrm{~W} \mathrm{~m}^{-2}$ around $2040-2050$ and a decline to $2.6 \mathrm{~W} \mathrm{~m}^{-2}$ in 2100 . It is the only scenario allowing for negative $\mathrm{CO}_{2}$ emissions.

- RCP4.5 (Clarke et al., 2007; Thomson et al., 2011) is a stabilization-without-overshoot scenario, with a nearly constant $\mathrm{RF}$ value of $4.5 \mathrm{~W} \mathrm{~m}^{-2}$ between 2070 and 2100 .

- RCP6.0 (Fujino et al., 2006; Masui et al., 2011) is similar to RCP4.5, but with a higher value $\left(6 \mathrm{~W} \mathrm{~m}^{-2}\right)$ of RF in 2100 and a much weaker stabilization.

- RCP8.5 (Riahi et al., 2007, 2011) is a rising pathway, with a $R F$ of $8.5 \mathrm{~W} \mathrm{~m}^{-2}$ in 2100 .

Although the RCPs span the whole range of possible climate policies, from the most stringent RCP2.6 to the noclimate-policy RCP8.5 scenario, they do not cover the full range of air pollution projections available in the literature and do not include, for instance, a business-as-usual scenario (van Vuuren et al., 2011a). All RCPs assume a correlation between increasing income (in terms of gross domestic product, GDP) and more stringent air pollution control strategies and mitigation measures. As a consequence, they are all characterized by a globally declining trend of air polluting emissions, which is not fully representative of the literature on air quality projections. This has to be considered when applying the RCPs in air quality studies, which is one of the goals of this paper. Nevertheless, we have chosen to apply the RCPs for analyzing aerosol impacts in the future given their increasing use in a large number of publications (e.g., Bellouin et al., 2011; Lamarque et al., 2011; Chalmers et al., 2012; Fiore et al., 2012; Takemura, 2012; Lamarque et al., 2013; Rotstayn et al., 2013; Unger et al., 2013; Smith and Bond, 2014), and in the recent IPCC AR5 (Kirtman et al., 2013).

The emission data has a resolution of $0.5^{\circ} \times 0.5^{\circ}$ in latitude and longitude and is divided in 12 sectors (including land transport, shipping and aviation). It includes reactive gases, aerosol and aerosol precursors, namely $\mathrm{NO}_{\mathrm{x}}, \mathrm{CO}, \mathrm{SO}_{2}, \mathrm{NH}_{3}$, non-methane hydrocarbons (NMHCs), $\mathrm{BC}$ and organic carbon (Lamarque et al., 2010). Details on the processing of the emission data for use in the EMAC model and on the additional data sets used for natural emission sources (dust, DMS, secondary organic aerosol and biogenic emissions) are provided in $\mathrm{R} 13$.

The aerosol module MADE treats both aerosol mass and number, and therefore requires number emission fluxes to be provided as well. Emissions have to be split in the different size modes (Aitken and accumulation) of the model. To this end, assumptions on the size distributions of emitted particles are necessary and depend on the considered sector and, in some cases, on the specific aerosol compounds, as was extensively discussed in R13. In the present paper we consider only one size distribution for the particle emissions of each transport sector, following the reference cases of R13.
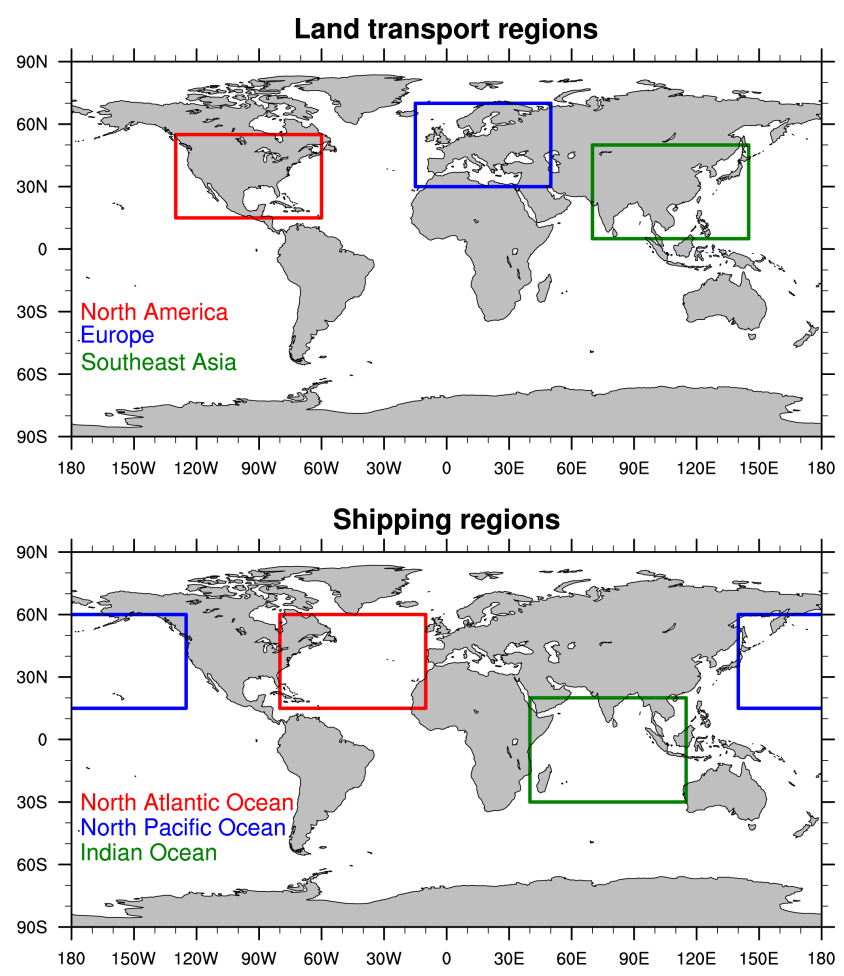

Figure 1. The regions selected for the analysis of the transport impacts: North America, Europe and Southeast Asia (top) for land transport; North Pacific, North Atlantic and Indian Ocean (bottom) for shipping.

For land transport, we consider the number size distribution parameters recommended by Dentener et al. (2006), which is characterized by a single emission mode (corresponding to the Aitken mode of MADE), with a median diameter of $30 \mathrm{~nm}$ and a geometric standard deviation of 1.8. The particle emissions from ships are parameterized by means of the size distribution measured by Petzold et al. (2008) in actual ship plumes: this results in a bimodal distribution with median diameters at 70 and $260 \mathrm{~nm}$, and standard deviations of 1.45 and 1.25 for the Aitken and the accumulation mode, respectively. The ratio of the total number concentrations of the Aitken mode to that of the accumulation model is about 134, the corresponding mass ratio is about 4 .

For the analysis of the impact of land transport sector emissions on global aerosol, we consider different continental regions: North America, Europe, and Southeast Asia (top panel of Fig. 1). The goal is to quantify the regional differences in the temporal evolution of the emissions and their effects on aerosol concentrations. Differences are especially expected between the developed countries (in Europe and USA) and the developing countries and fast-growing economies (India, China and other Asian countries). A similar analysis is performed for the shipping sector, focusing on specific oceanic areas, where the impact of ship emissions was found to be large in R13, namely the North Atlantic, the 
North Pacific and the Indian Oceans (bottom panel of Fig. 1). The results for the individual regions are then compared with the global impacts for both sectors.

The relative changes in emissions between 2000 and 2030 in the four RCP scenarios are shown in Fig. 2 for selected species and for the regions defined above. In general, all scenarios project a decrease in land transport emissions on the global scale for all species, with the exception of RCP4.5 (increase in $\mathrm{SO}_{2}$ and small increase in $\mathrm{BC}$ and $\mathrm{POM}$ ) and $\mathrm{RCP} 2.6$ (increase in $\mathrm{BC}$ and POM). When considering the different regions, it is interesting to see that land transport emissions in North America and Europe decrease in all scenarios, in view of the mitigation strategies applied in these regions. For most of the analyzed pollutants, RCP8.5 is the scenario with the strongest reduction in emissions, in spite of its high long-term climate impacts. However, land transport emissions are strongly increasing in Southeast Asia, with the exception of $\mathrm{NH}_{3}$ (all scenarios), $\mathrm{NO}_{\mathrm{x}}$ and $\mathrm{SO}_{2}$ in $\mathrm{RCP} 2.6$, and $\mathrm{BC}$ and POM in RCP6.0 and RCP8.5.

With regard to shipping emissions, all scenarios agree in the $\mathrm{SO}_{2}$ reduction, following the implementation of new limitations to fuel sulfur content in shipping starting from the year 2010 (Buhaug et al., 2009). The highest (smallest) reduction is projected in RCP2.6 (RCP4.5), around $80 \%$ $(20 \%)$. The other species are expected to increase in RCP4.5 and RCP8.5, and to decrease in the other two scenarios (with the exception of $\mathrm{NO}_{\mathrm{x}}$ which is slightly increasing in RCP2.6). The pattern of changes is identical in the three oceanic regions considered for this sector. This is a consequence of the fact that the RCPs do not consider changes in the geographical distribution of shipping routes but simply apply a scaling factor to estimate future emissions.

Despite the potential inconsistencies of these emission changes, their simulated effects on atmospheric aerosol and radiation are discussed in the following sections.

\section{Impacts on aerosol surface-level concentrations and burdens}

As mentioned in Sect. 2, the impacts of the emissions from a given sector on the aerosol concentrations are calculated here using a $100 \%$ perturbation approach. For each of the scenarios, we perform a reference simulation $\left(\mathrm{REF}_{\mathrm{RCP}}\right)$, including all emission sources, and a sensitivity simulation where the emission from either land transport

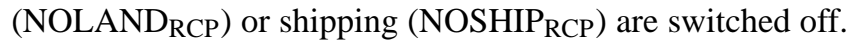
The impact of, e.g., land transport for a given RCP is then calculated as

$\Delta_{\mathrm{RCP}}^{\mathrm{LAND}}=\mathrm{REF}_{\mathrm{RCP}}-\mathrm{NOLAND}_{\mathrm{RCP}}$.

In the following, we will discuss the changes $D$ in transportinduced surface-level concentrations between 2000 and 2030 for the different scenarios. For land transport, this is given by the difference:

$D_{\mathrm{RCP}}^{\mathrm{LAND}}=\Delta_{\mathrm{RCP}}^{\mathrm{LAND}}-\Delta_{2000}^{\mathrm{LAND}}$.

To provide a more complete view on the changes in transportinduced aerosols, we will relate this to the changes in total concentration,

$D_{\mathrm{RCP}}^{\mathrm{ALL}}=\mathrm{REF}_{\mathrm{RCP}}-\mathrm{REF}_{2000}$,

and to the changes in the concentrations induced by other (non-land-transport) sources:

$D_{\mathrm{RCP}}^{\mathrm{OTHER}}=\mathrm{NOLAND}_{\mathrm{RCP}}-\mathrm{NOLAND}_{2000}$.

Note that, of course, $D_{\mathrm{RCP}}^{\mathrm{ALL}}=D_{\mathrm{RCP}}^{\mathrm{LAND}}+D_{\mathrm{RCP}}^{\mathrm{OTHER}}$.

An identical approach is applied to quantify the effects of shipping, using the NOSHIP instead of the NOLAND experiment in the equations above.

\subsection{Land transport}

The impacts of land transport emissions on large-scale mean surface-level concentrations are presented in Figs. 3-5 for $\mathrm{BC}$, aerosol nitrate $\left(\mathrm{NO}_{3}\right)$, which are the most relevant pollutants from this sector (R13), and number concentration of fine particles $(\lesssim 1 \mu \mathrm{m}$, calculated as the sum of the Aitken and accumulation mode particles). The analogous figures for other compounds, (POM, $\mathrm{SO}_{2}$ and aerosol ammonium $\left(\mathrm{NH}_{4}\right)$ ) are provided in the Supplement (Figs. S1-S3).

The first row of these figures shows the concentrations induced by all sources $\left(\mathrm{REF}_{2000}\right)$, by land transport only $\left(\Delta_{2000}^{\mathrm{LAND}}\right)$ and by other sources $\left(\mathrm{NOLAND}_{2000}\right)$ in the year 2000 , as calculated in R13. The corresponding changes between 2000 and 2030, as calculated from Eqs. (2-4), are given in the other rows.

The general tendency shown by these figures is a decrease in aerosol surface-level concentrations over the developed countries (USA, European countries and Japan) and an increase in the countries with fast-growing economies (in Southeast Asia). This applies to the total concentrations (as also found by Takemura (2012) using the SPRINTARS model) as well as to the land-transport-induced concentrations. Such decreasing concentrations in the developed countries is a common feature of all RCPs, but there are some exceptions discussed in detail below. Most importantly, the changes in the aerosol concentrations are different from what could be expected from the RCP rankings: scenarios with the most stringent climate policies and with the strongest longterm reductions in global climate effects (like RCP2.6) show sometimes an opposite behavior in terms of short-lived pollutants from specific sectors and regions.

The largest reductions of the land transport impact on $\mathrm{BC}$ surface-level concentration (Fig. 3) are simulated for Europe, in particular for RCP8.5, with local reductions of up to $1 \mu \mathrm{g} \mathrm{m}^{-3}$. Significant reductions $\left(0.1-0.5 \mu \mathrm{g} \mathrm{m}^{-3}\right)$ are also found for the USA, Japan and some large metropolitan areas 
Land transport - Global

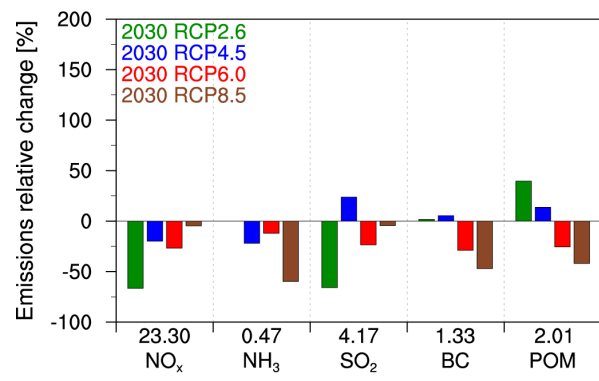

Land transport - North America

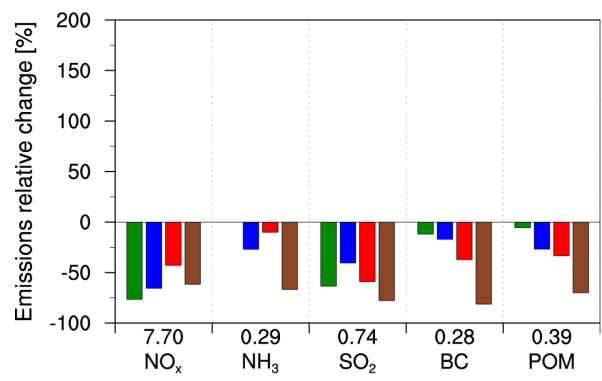

Land transport - Europe

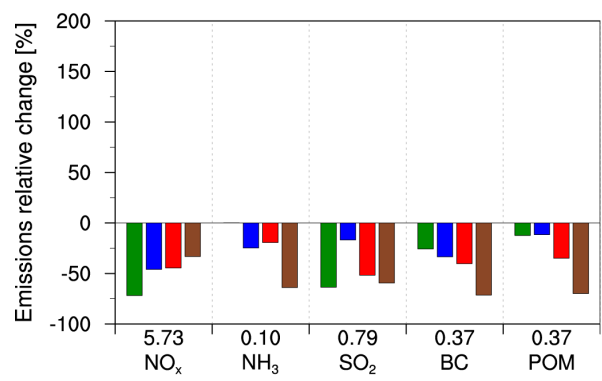

Land transport - Southeast Asia

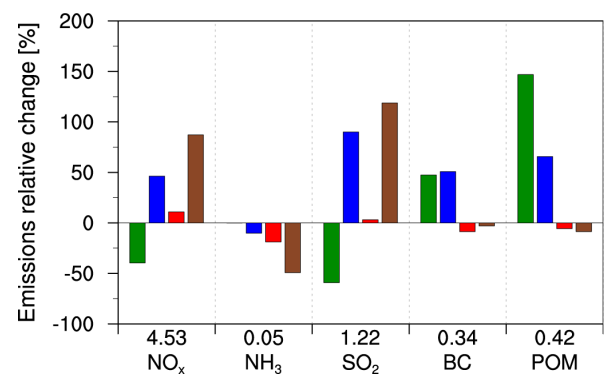

Shipping - Global

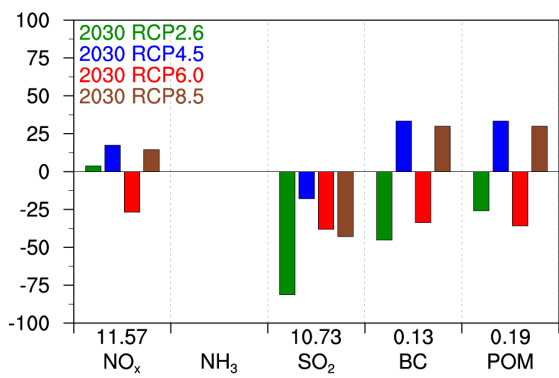

Shipping - North Atlantic Ocean

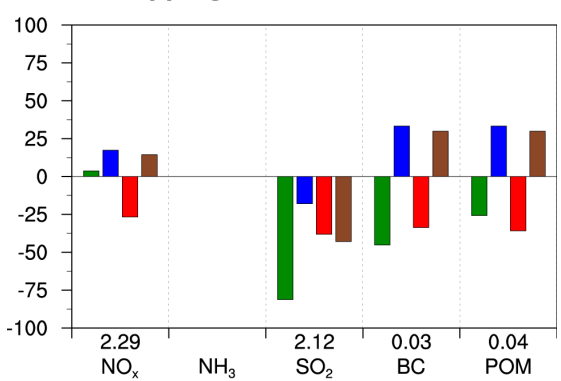

Shipping - North Pacific Ocean

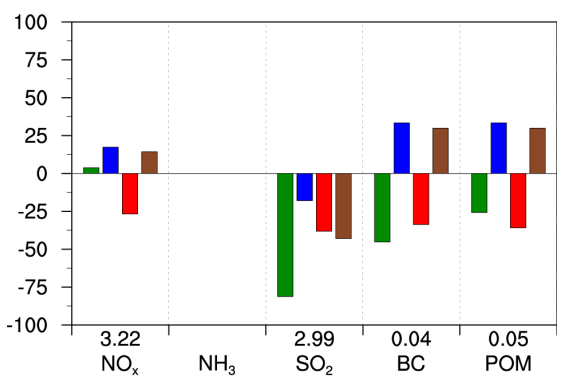

Shipping - Indian Ocean

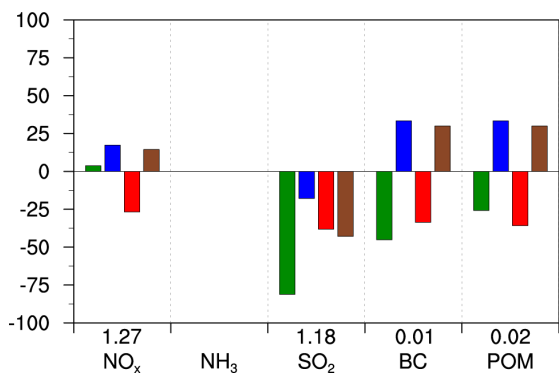

Figure 2. Relative changes in the emissions from land transport (left) and shipping (right) in the year 2030 with respect to 2000 , for the four RCP scenarios. The changes are calculated globally (top row) and for the regions defined in Fig. 1 (bottom three rows). Total emissions for the year 2000 are shown at the bottom of each panel, in units of $\operatorname{Tg}($ species $) \mathrm{a}^{-1}$ and $\operatorname{Tg}(\mathrm{NO}) \mathrm{a}^{-1}$ for $\mathrm{NO}_{\mathrm{x}}$. Note the different vertical scales for the two sectors.

(especially in South America). This result is not surprising, in view of the findings of R13 for the year 2000, in which land transport was responsible for the bulk of BC surface-level pollution in these regions (up to about $70 \%$ ). Air pollution control policies in such regions must necessarily address the land transport sector in order to reduce pollution. Compared with the changes in other sources (right column of Fig. 3), it is clear that land transport drives a major portion of the reduction trend in the developed countries in 2030 in all scenarios. In Southeast Asia, however, this is not always the case and $\mathrm{BC}$ pollution is mostly driven by other sources. A general increase in land-transport-induced BC surface-level con- 


\section{Land transport impacts on BC}
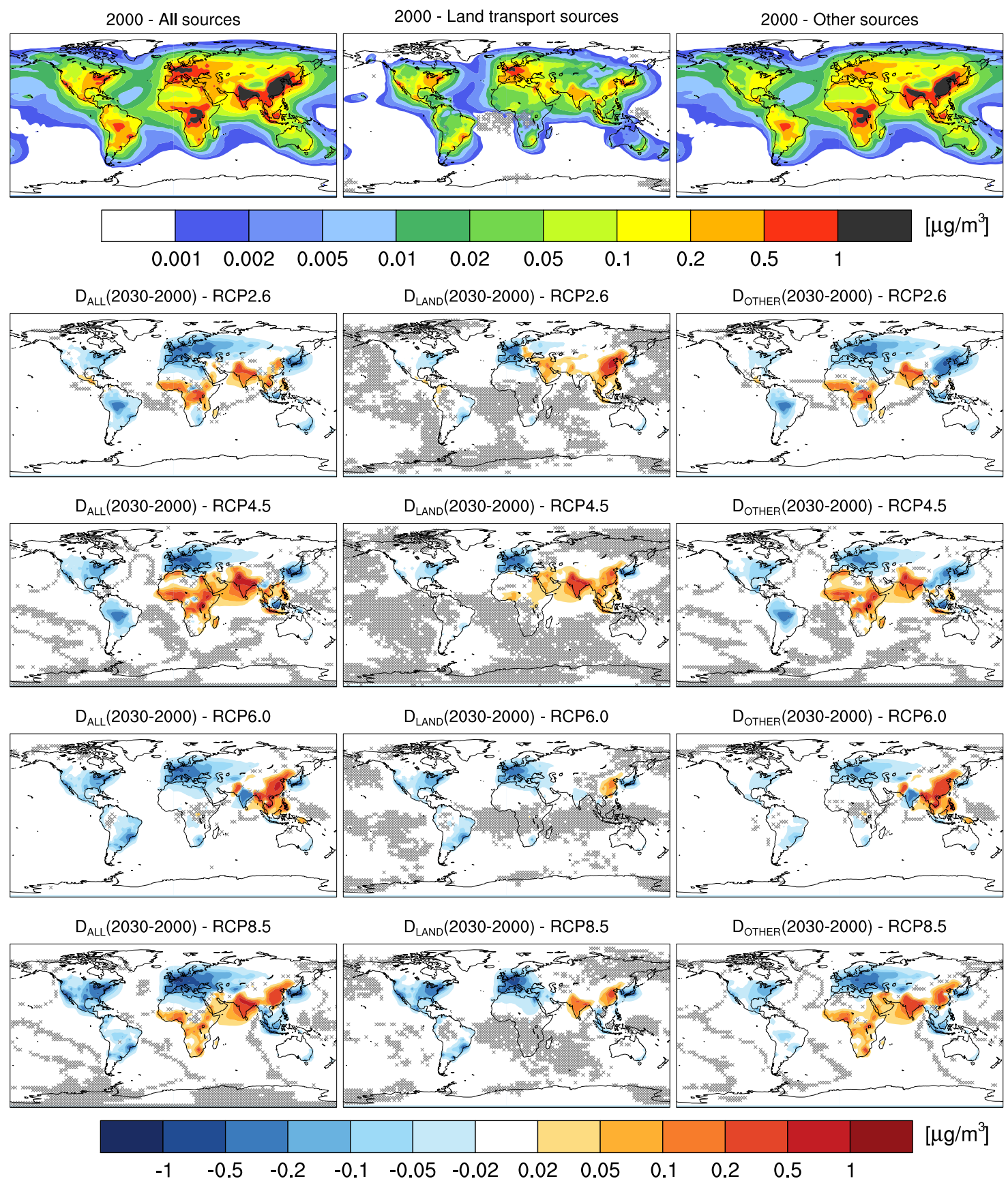

Figure 3. Annual average large-scale mean surface-level concentrations of BC. The first row shows the values for 2000: total concentration $\left(\mathrm{REF}_{2000}\right.$, left), the concentration induced by land transport $\left(\Delta_{2000}^{\mathrm{LAND}}\right.$, middle) and the concentration induced by other sources $\left(\mathrm{NOLAND}_{2000}\right.$, right). The other rows show the changes in the same quantities between 2000 and 2030 for the four RCPs, as given in Eqs. (2-4). Grid points where the difference is not statistically significant according to a univariate $t$ test (5\% error probability) are hatched.

centration in this region is evident in all scenarios (with the exception of RCP6.0), but its impact on the overall changes varies among the scenarios and there are quite marked differences between southern and eastern Asia. In RCP2.6, for instance, the impact of land transport in southern Asia does not change between 2000 and 2030, while it increases significantly in eastern Asia, completely counteracting the decrease in the trend of other sources. 


\section{Land transport impacts on $\mathrm{NO}_{3}$}
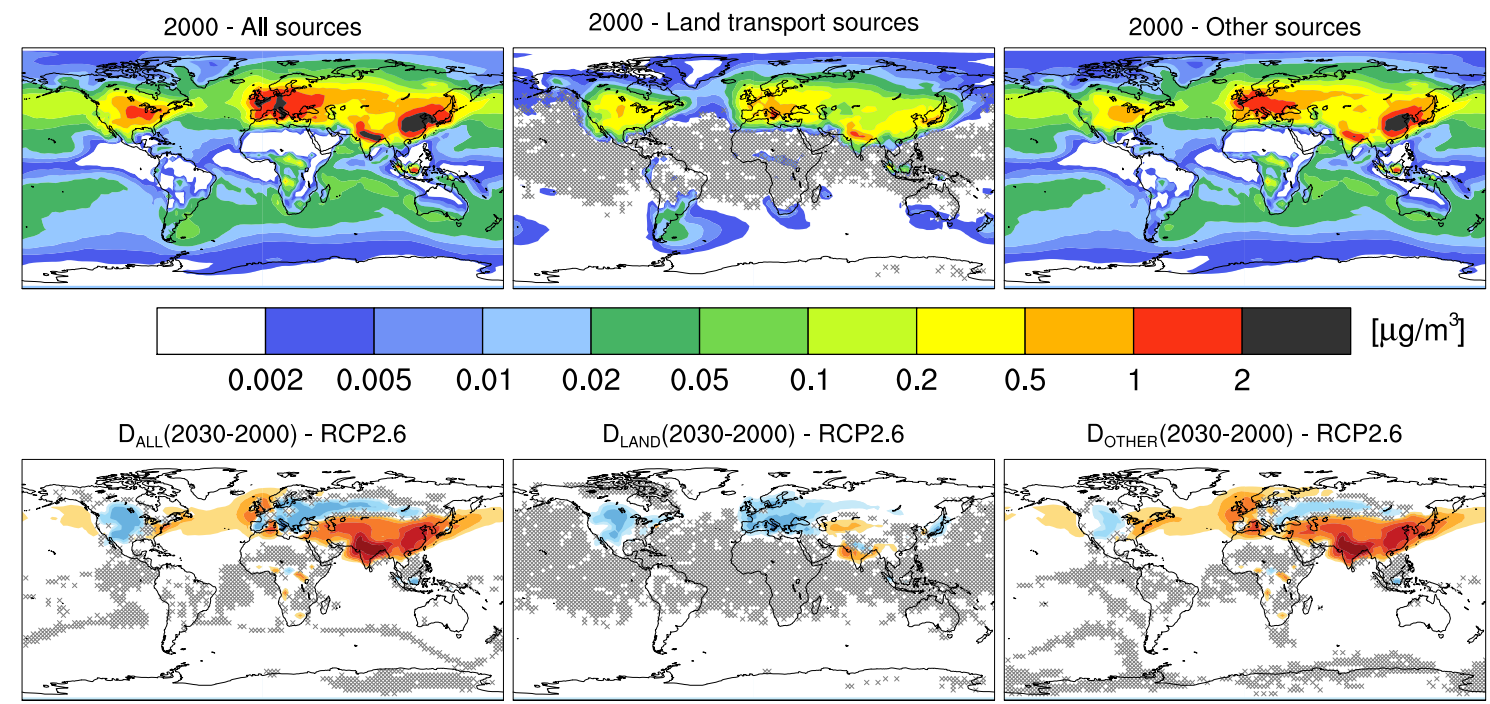

$0.02 \quad 0.05$
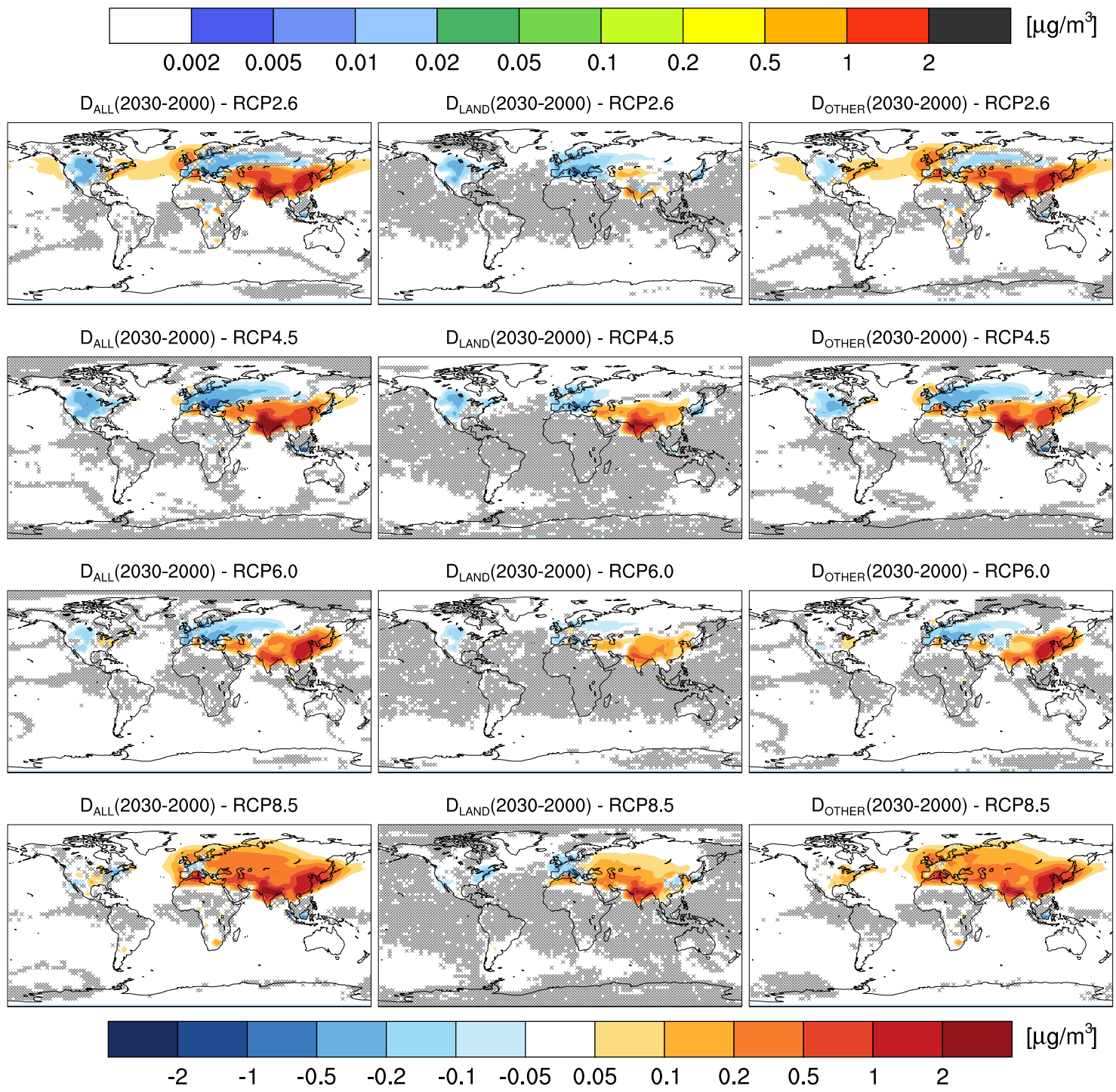

Figure 4. As in Fig. 3, but for aerosol nitrate concentrations.

Aerosol nitrate is another important pollutant induced by land transport emissions. The simulations by R13 revealed that land transport emissions were responsible for up to 50$70 \%$ of surface-level nitrate concentrations in the year 2000, in particular over North and South America. In Europe and Southeast Asia the contributions are smaller. These proportions can also be found in the patterns of changes towards
2030 in most scenarios (Fig. 4). While land transport mostly drives the temporal changes in North America, other sources have major impacts in the other regions. Changes in total nitrate surface-level concentrations are characterized by small decreases in the developed countries (between about $1 \mu \mathrm{g} \mathrm{m}^{-3}$ in RCP4.5 and less than $0.1 \mu \mathrm{g} \mathrm{m}^{-3}$ in RCP8.5). Increases in Southeast Asia, however, are very large (up to 


\section{Land transport impacts on $\mathbf{N}_{\text {tot }}$}
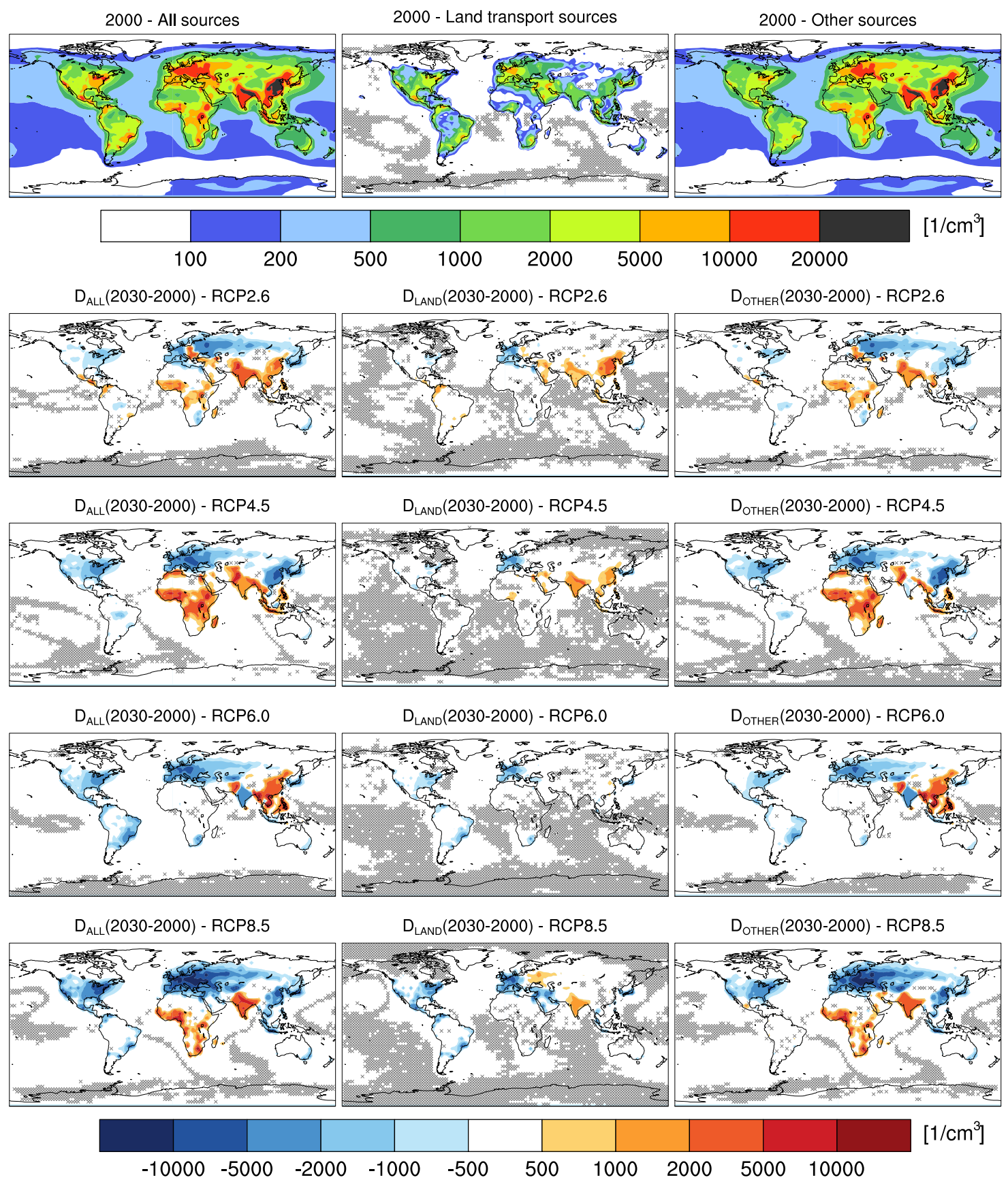

Figure 5. As in Fig. 3, but for fine particle $(\lesssim 1 \mu \mathrm{m}$, sum of the Aitken and accumulation mode particles) number concentrations.

$5 \mu \mathrm{g} \mathrm{m}^{-3}$ in RCP4.5). No significant changes are simulated for the Southern Hemisphere.

The changes in aerosol mass concentrations directly correspond to the changes in particle number concentrations (Fig. 5). This is particularly the case for primary particles, which directly increase particle number concentration. It is interesting to note, however, that in many cases land transport has only a comparatively small impact on the overall changes in particle number concentrations. Such changes seem to be mostly attributable to other sources, in particular the sources emitting significant amounts of POM (Fig. S1 in the Supplement). We recall, however, that particle number emissions in the model are calculated assuming externally mixed particles (see R13, for details) and that such assumption may not 

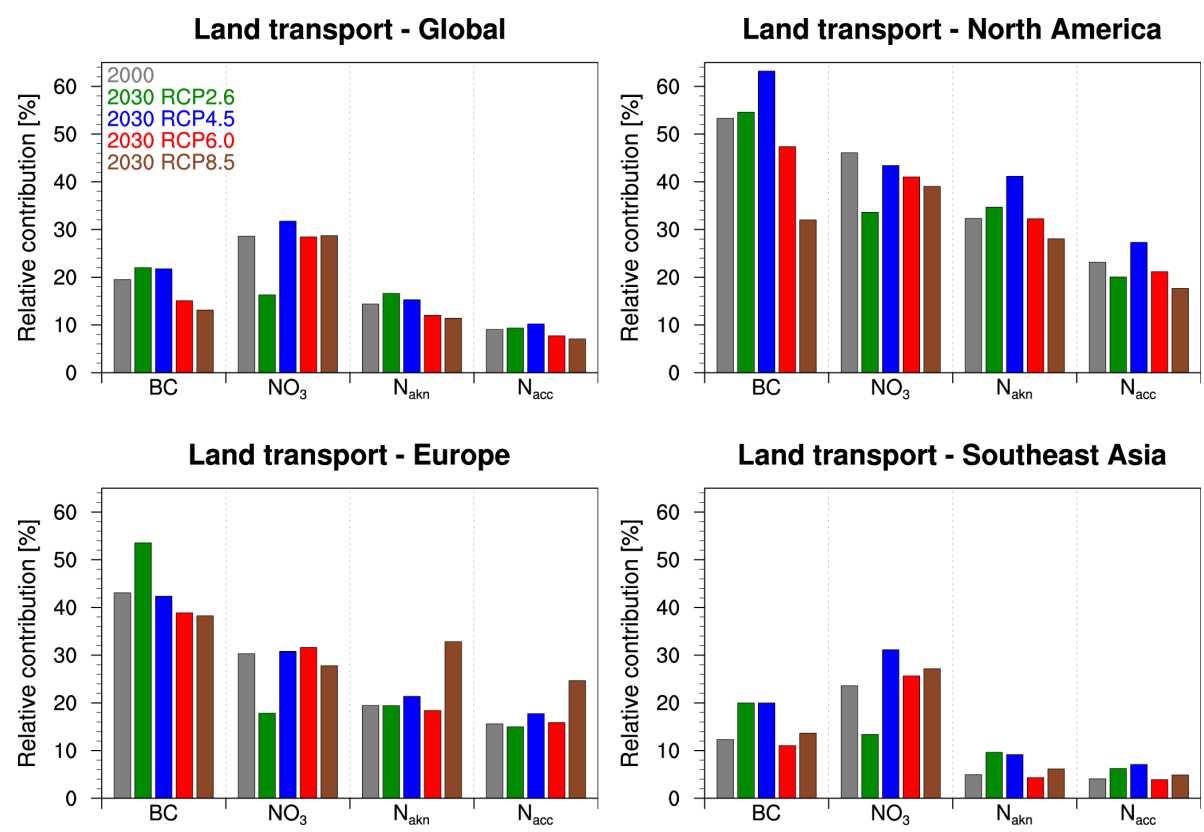

Figure 6. Relative contributions of land transport to the average mass and number burdens of selected aerosol species and different particle size modes (Aitken and accumulation mode), respectively. Results are shown for the year 2000 and for the four RCP scenarios in 2030 . The values are integrated over the continents and in the two lowermost model layers $(\sim 0-230 \mathrm{~m})$. For the definition of the different regions see Fig. 1.

always be valid for combustion processes. Changes in total concentrations are largest in RCP8.5, in particular for Europe, with decreases of around $5000-10000 \mathrm{~cm}^{-3}$. Overall, the land-transport-induced changes in particle number follow the pattern of changes in mass, although increases in Southeast Asia are generally quite small, especially for RCP6.0 and RCP8.5.

As discussed in R13, the estimates on particle number concentrations critically depend on the assumed size distributions of the emitted particles. The related uncertainty is particularly high for the land transport sector, where it can be as high as 1 order of magnitude in the simulated local concentrations. The sign of the estimated changes, however, should be less affected by this uncertainty, as long as one can further assume that the size distribution of particles emitted by land transport does not change significantly between 2000 and 2030. This hypothesis, however, would need to be tested, considering the change in the vehicles properties in the future, which may even depend on the regions under consideration. Such an analysis, however, is beyond the scope of the present study.

To summarize the above results and further characterize the effect of the land transport sector on air quality, we close this section discussing the relative contributions of land transport to the aerosol near-surface burdens, depicted in Fig. 6 for the regions defined in Fig. 1 and for the globe. These plots highlight the large regional differences in the contribution of land transport to near-surface pollution. In the year 2000, this sector accounts globally for about $20 \%$ of the near-surface burden of BC (R13), but it has a much higher impact in Europe and North America than in Southeast Asia, where the near-surface BC pollution is mostly driven by other sources (e.g., industries and domestic heating). These large regional differences are still present in 2030 in all RCPs. Given these relative contributions, Europe and North America have a particularly effective BC reduction potential from land transport, due to emission regulations and the implementation of technological measures. However, the reduction of the land transport impact on BC is larger in North America than in Europe, since in the latter region emission regulations are already established. In Southeast Asia, however, the land transport share grows for most of the scenarios. The land transport contribution to $\mathrm{NO}_{3}$ nearsurface burden, on the other hand, is nearly constant for all RCPs, with the exception of RCP2.6. In terms of particle number, the land-transport-induced burden is characterized by small variations between 2000 and 2030, for all RCPs, although there are some notable exceptions. The number burden share of land transport grows significantly in Europe under the RCP8.5 scenario, due to the large decrease of the contribution of other sources (see Fig. 5). In Southeast Asia, the contribution of land transport to number burden is dominated by primary particles, since in this region aerosol pollution is mostly driven by primary anthropogenic aerosol. 


\section{Shipping impacts on $\mathrm{SO}_{4}$}
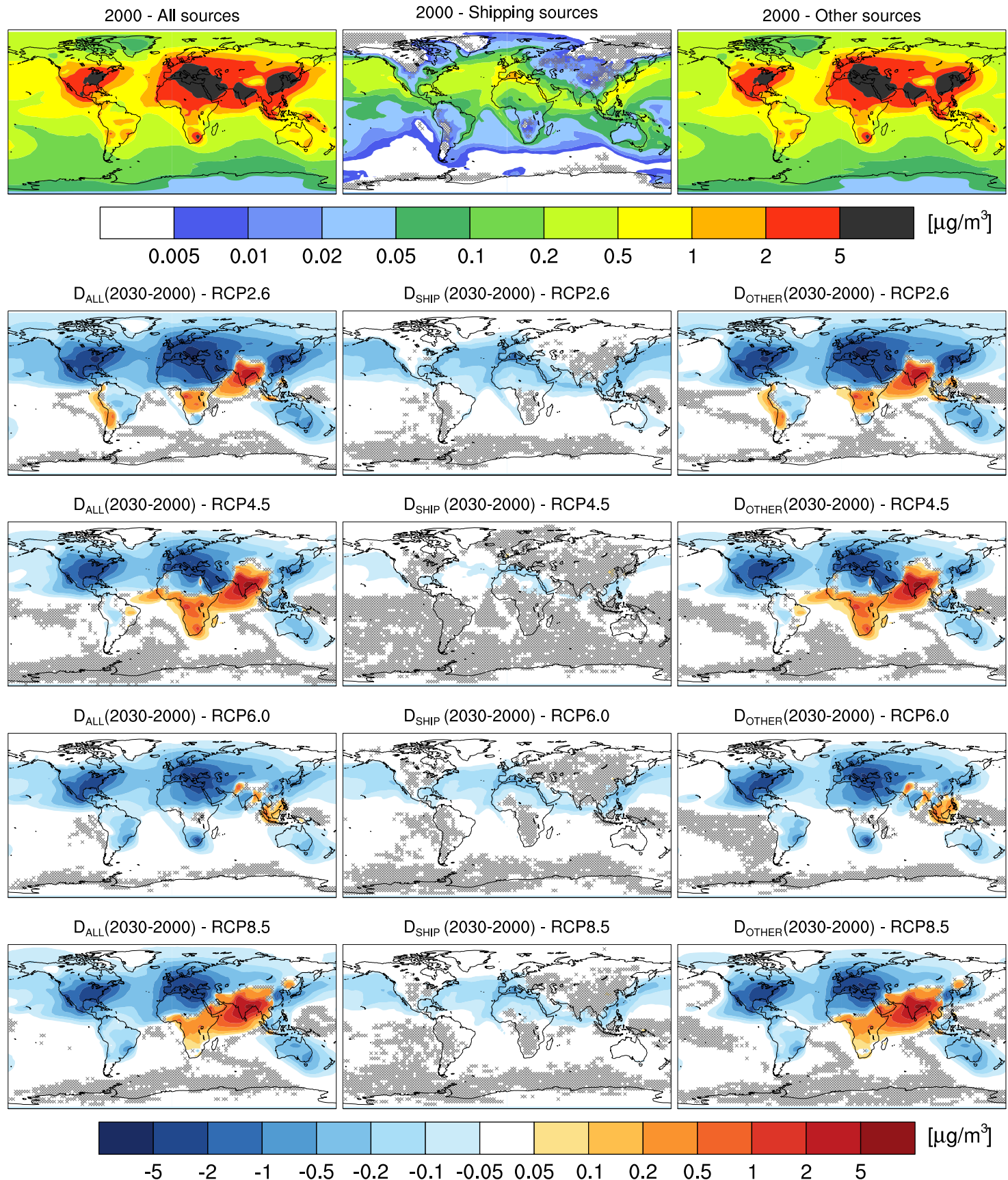

Figure 7. Annual average large-scale mean surface-level concentrations of sulfate. The first row shows the values for 2000: total concentration $\left(\mathrm{REF}_{2000}\right.$, left), the concentration induced by shipping $\left(\Delta_{2000}^{\mathrm{SHIP}}\right.$, middle) and the concentration induced by other sources (NOSHIP 2000 , right). The other rows show the changes in the same quantities between 2000 and 2030 for the four RCPs, as in Figs. 3-5. Grid points where the difference is not statistically significant according to a univariate $t$ test ( $5 \%$ error probability) are hatched.

\subsection{Shipping}

Our simulations reveal that the emissions from shipping have a relevant impact on the concentrations of $\mathrm{SO}_{4}, \mathrm{NO}_{3}$ and fine particle number (Figs. 7-9, respectively, first rows), in particular in the North Pacific, North Atlantic and Indian Ocean. This also justifies the choice of the regions shown in Fig. 1 for the analysis (see also Sect. 3). Over the continents, the 


\section{Shipping impacts on $\mathrm{NO}_{3}$}
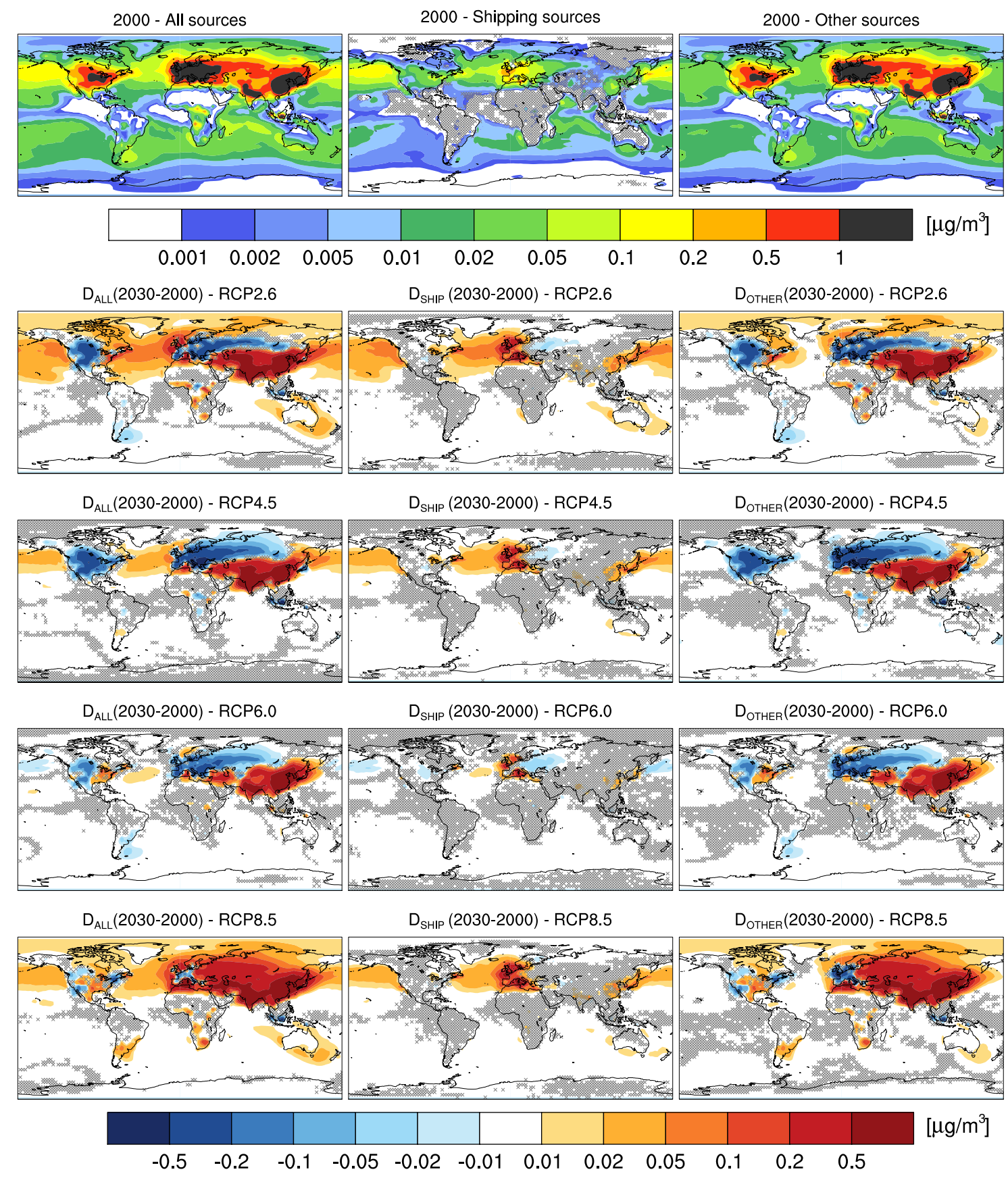

Figure 8. As in Fig. 7, but for aerosol nitrate concentrations.

sulfate pollution is dominated by other sources. The impact of shipping is however nonnegligible close to the coastal regions, in particular in the Mediterranean Basin, where it contributes $10-20 \%$ of the surface-level concentration in 2000 (R13). The modeled surface-level concentrations of the other compounds (BC, POM and $\mathrm{NH}_{4}$ ) are dominated by continental sources, which also have a large impact over the oceans due to long-range atmospheric transport effects (see Figs. S4-S6 in the Supplement).

The pattern of changes shows a clear decrease in shippinginduced sulfate, mostly confined to the Northern Hemisphere (Fig. 7). This is a consequence of the new regulations for shipping fuel which limit the fuel sulfur content, starting from 2010 (Buhaug et al., 2009). Such regulations are ac- 


\section{Shipping impacts on $\mathbf{N}_{\text {tot }}$}
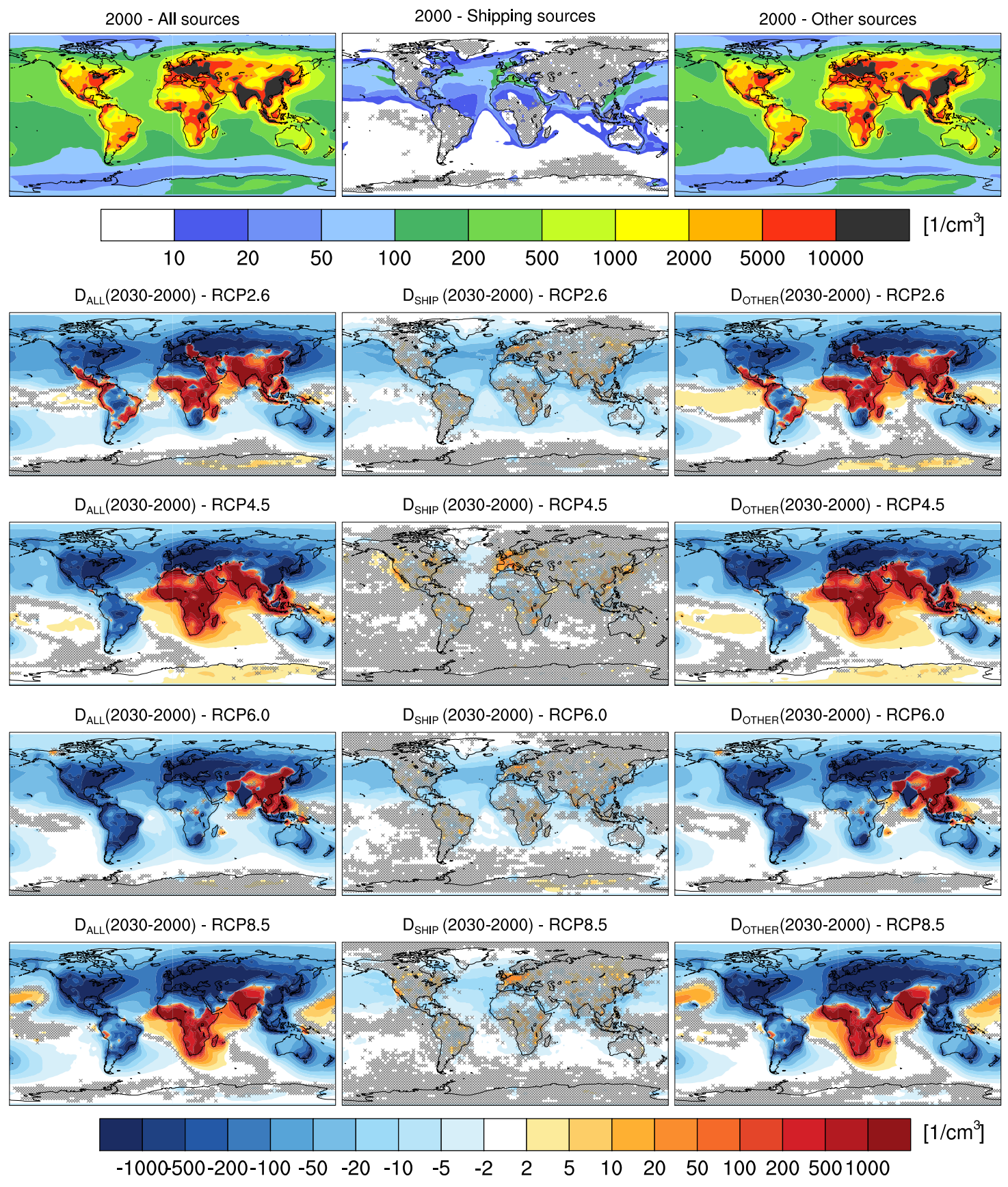

Figure 9. As in Fig. 7, but for fine particle $(\lesssim 1 \mu \mathrm{m}$, sum of the Aitken and accumulation mode particles) number concentrations.

counted for in the RCPs. It is interesting to note that total sulfate is projected to decrease quite strongly in the continental regions and in the coastal areas (with the exception of southern Asia, southern Africa and South America) in all scenarios, but the contribution of shipping to this trend is only marginal, around $0.5 \mu \mathrm{g} \mathrm{m}^{-3}$, whereas the concentration induced by other sources decrease by several micrograms per cubic meter. In RCP2.6, for example, the assumed climate policies to reduce greenhouse gas emissions lead also to a simultaneous reduction of short-lived pollutants. For $\mathrm{SO}_{2}$, in particular, the reduction in emission derives from the reduced coal use in the energy production sector (van Vuuren et al., 2011b). 
Righi et al. (2011) analyzed future scenarios of lowered sulfur emissions from shipping for a set of alternative fuels (including biofuels). They simulated up to about $40-60 \%$ reduction in shipping-induced sulfate concentration along the major shipping routes of the Indian Ocean, the northern Pacific Ocean, and the central Atlantic Ocean. A similar relative reduction is found also for the scenarios discussed here, in particular for RCP6.0 and RCP8.5, although the pattern of changes is different due to the different emission data used.

The shipping impacts on sulfate pollution are strongly correlated with aerosol nitrate effects, given that the formation of both compounds in fine particles is controlled by the availability of ammonia. The formation of ammonium sulfate is favored over ammonium nitrate, therefore ammonium nitrate can be formed only if there is an excess of ammonia available after the formation of ammonium sulfate (Seinfeld and Pandis, 1998). Given the strong reduction in sulfate discussed above, the competition between sulfate and nitrate for available ammonia is of particular relevance for this sector. A lower concentration of $\mathrm{SO}_{2}$ in the marine boundary layer makes more ammonia available for the formation of ammonium nitrate and therefore results in an increase of the aerosol nitrate concentration. The results of our simulations (Fig. 8) support this line of reasoning: the increasing trend in nitrate concentration over the oceans is almost completely driven by shipping in all scenarios, with the largest effect simulated in the Northern Hemisphere. The only exception is RCP6.0, for which a slight reduction in nitrate is simulated over the Pacific. This reduction stems from a significant reduction in $\mathrm{NO}_{\mathrm{x}}$ emissions from shipping, partly compensated by a reduction in sulfate concentration.

The combined effect of $\mathrm{SO}_{4}$ and $\mathrm{NO}_{3}$ shows that the regulations aiming at reducing $\mathrm{SO}_{2}$ emissions should also consider reductions in aerosol nitrate precursors $\left(\mathrm{NO}_{\mathrm{x}}\right.$ and $\mathrm{NH}_{3}$ ) in order to achieve a reduction in aerosol concentration (Kharol et al., 2013) and in aerosol-induced climate impacts (Bellouin et al., 2011). It should be noted that sulfate and nitrate could also be taken up by sea salt particles. In this case a similar competition as described above can occur between the formation of sodium sulfate and sodium nitrate. Due to their large surface area concentration, fine particles can take up sulfate more efficiently than the comparatively large sea salt particles. Hence, we neglected interactions of reactive gases with coarse mode aerosol in the model version applied here.

Sulfate is also central in determining the shipping effect on particle number concentration (Fig. 9). A general decreasing trend of the shipping effects is found in all scenarios, although it is less marked in RCP4.5 and RCP8.5. These two scenarios are characterized by an increase in primary particle emissions (Fig. 2, top-right panel), which contributes to number concentrations and slightly counteract the sulfate-driven reduction. In Sect. 5, we shall discuss how these changes affect the estimates of the aerosol-induced RF effects from this sector.
As for the land transport sector, we summarize this discussion analyzing the contribution of shipping to the nearsurface aerosol burden in Fig. 10. An important difference with respect to the land transport sector is that the RCP scenarios do not implement any change in the geographical distribution of shipping emissions with respect to 2000 . This is the reason why the different regions in Fig. 10 are characterized by a similar pattern of changes between 2000 and 2030. An exception is the Indian Ocean region (Fig. 10, bottom-right panel), which is strongly affected by the pollution from the Asian continent which in turn can impact the oceanic background and lead to some differences in the resulting contribution of shipping to the near-surface burden. Sulfate and nitrate are the most important contributors to near-surface pollution over the oceans, with a relative value of $14 \%$ and $24 \%$ in 2000 (R13), respectively. In the future scenarios, there is a general anticorrelation between these two species, due to the aforementioned competition effect for ammonia, whereby large decreases in $\mathrm{SO}_{4}$ are counteracted by increases in $\mathrm{NO}_{3}$. The shipping impact on particle number concentration is generally smaller than for land transport, due to the relatively large sizes of the particles emitted by ships (Petzold et al., 2008). Globally, the relative contribution of shipping to particle number burden close to the ocean surface is below $5 \%$ for both size modes, but is quite relevant in the North Atlantic and North Pacific ocean, both in 2000 and 2030 for all RCPs. As previously mentioned, the effects on number concentration from this sector are mostly driven by sulfate. Given that shipping is the main source of anthropogenic pollution in the marine boundary layer, even a relatively small perturbation to aerosol particle number concentration can produce a large effect on clouds and on the radiative balance, as we shall show in the next section.

\section{Transport impacts on climate}

Aerosol-induced impacts on Earth's radiation budget due to transport emissions are quantified here as the changes in the radiative fluxes at the top of the atmosphere (cf. Lohmann and Feichter, 2005; Schulz et al., 2006). We consider the combined effect of longwave and shortwave radiation and analyze the all-sky radiative flux (considering both cloudy and clear-sky conditions) as well as the clear-sky flux only. The latter is derived from radiative flux calculations neglecting the effects of clouds and can be used to infer the importance of clouds and cloud modifications for the radiation budged (see R13, for more details). Transport-induced changes in the radiation fluxes can be interpreted as the RF of the aerosol changes caused by transport emissions. The global-mean RF obtained for the year 2000 and for the four RCPs in 2030 are presented in Fig. 11. The values for the year 2000 plotted in this figure are taken from the companion paper (R13) and correspond to the reference case, although in that paper a range of possible values was found. This range is marked 

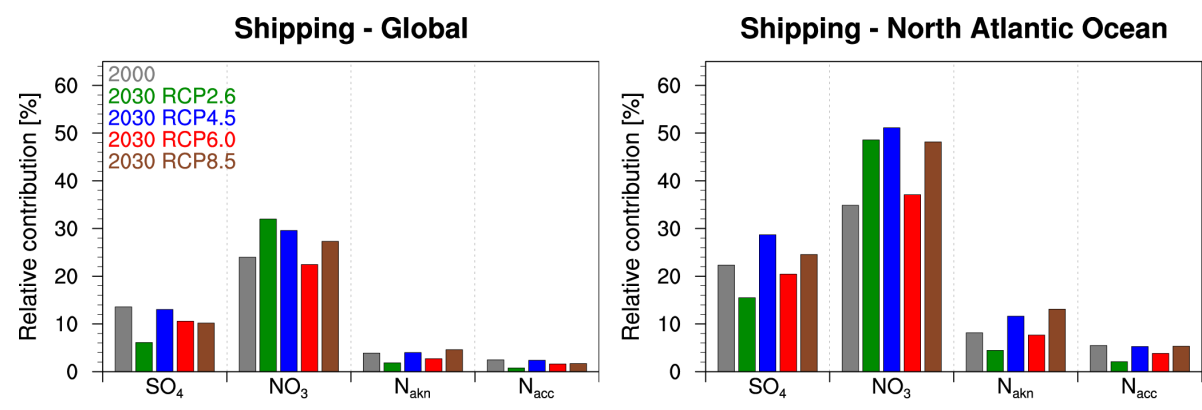

Shipping - North Pacific Ocean
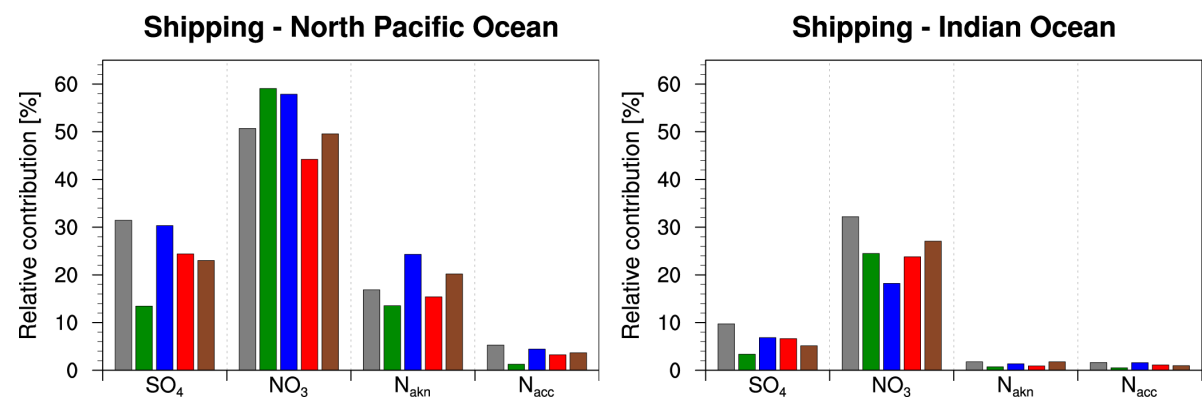

Figure 10. Relative contributions of shipping to the average mass and number burdens of selected aerosol species and different particles size modes (Aitken and accumulation mode). Results are shown for the year 2000 and for the four RCP scenarios in 2030 . The values are integrated over the oceans and in the two lowermost model layers $(\sim 0-230 \mathrm{~m})$. For the definition of the different regions see Fig. 1.

by the open boxes in Fig. 11 and can be interpreted as the uncertainty in the transport-induced RF due to the assumptions on the size distribution of emitted particles. We refrain from repeating the same uncertainty analysis in the present paper, given the large number of expensive additional experiments that this would require. To give a hint of the uncertainty associated with the RF values in 2030, we assumed that the uncertainty range calculated for 2000 can (in relative terms) be applied to future scenarios by simply rescaling the corresponding 2030 value according to the upper and lower values for 2000. The rescaling is given only for the all-sky values, since clear-sky values are mostly small or not significant, and hence such a scaling can be critical. However, we can still conclude that the all-sky aerosol forcing is much larger than the corresponding clear-sky value for all sectors and scenarios, suggesting a dominant influence of aerosolinduced cloud modifications on the RF of aerosol changes resulting from transport emissions.

The land-transport-induced aerosol RF (Fig. 11, left panel) shows a reduction of the cooling effect from $-80 \mathrm{~mW} \mathrm{~m}^{-2}$ in 2000 to about $-60 \mathrm{~mW} \mathrm{~m}^{-2}$ in 2030 . As mentioned above, these values represent the upper limit corresponding to the reference case. The lower limit is about a factor of 7 smaller and corresponds to assuming an aged size distribution for the emitted particles (R13). Since the bulk of the RF impact is due to cloud effects, it is mostly controlled by changes in particle number concentration in the activated size range (which roughly corresponds to our accumulation mode). The absolute land-transport-induced change in accumulation particle number burden is quite similar among the scenarios (about $2-3 \times 10^{24}$ particles on average, not shown), which explains the small differences in $2030 \mathrm{RF}$ among the four RCPs for the land transport sector.

The shipping impacts (Fig. 11, right panel) are characterized by a strong decrease of the aerosol-induced RF in $\mathrm{RCP} 2.6$, dropping from -181 in 2000 to $-53 \mathrm{~mW} \mathrm{~m}^{-2}$ in 2030 as a consequence of the fuel sulfur control measures implemented in the shipping sector, which significantly affect the sulfate burden. This factor of 3-4 reduction in aerosol forcing is in good agreement with the results of Righi et al. (2011) for future low-sulfur shipping scenarios, whereas Lauer et al. (2009) simulated a factor of 2 reduction in aerosol-induced RF following a global reduction of fuel sulfur content from 2.7 to $0.5 \%$ by mass. Smaller reductions are projected for the other scenarios, consistent with the corresponding changes in tropospheric sulfate burdens (Fig. 10). The uncertainty range due to the assumed size distribution of emitted particles is relatively small for the shipping sector, as discussed in R13.

The results in Fig. 11 show that despite a significant growth in traffic volume, the aerosol-related climate impacts do not increase. We however stress again the fact that the RCP scenarios are quite optimistic in terms of air quality policies and that they do not include a business-as-usual scenario. Hence, the consideration of alternative, more realistic air pollution scenarios may lead to different conclusions in this regard. In the case of land transport, new regulations are limiting the emissions in the developed countries, where this 

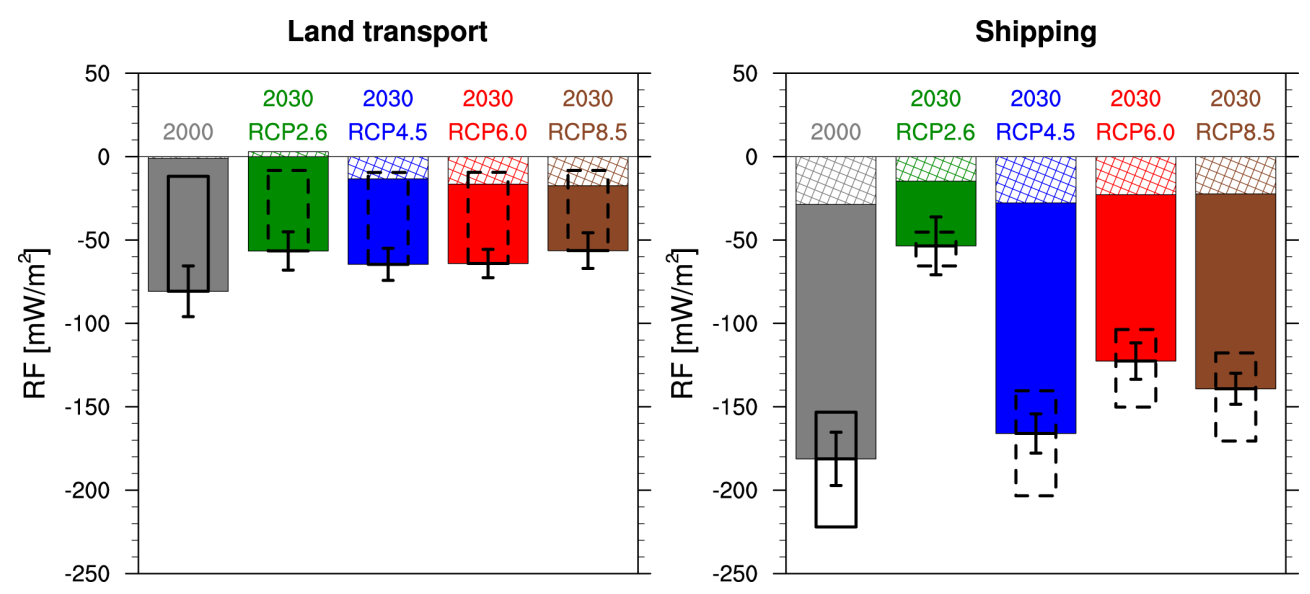

Figure 11. Global mean all-sky RF resulting from the emissions of land transport (left) and shipping (right) in the year 2000 (gray bars) and for the four RCP scenarios in 2030 (colored bars). The hatched part of each bar is the corresponding clear-sky forcing, calculated neglecting the effects of clouds. The whiskers represent the $95 \%$ confidence interval. The boxes correspond to the uncertainty range derived from the assumptions on the size distribution of emitted particles, as calculated by R13 for year 2000 (solid) and rescaled here to the 2030 values (dashed).

sector is still one of the main sources of pollution. In developing countries and fast-growing economies (e.g., southern and eastern Asia), the emissions are expected to continue growing in the near future, as discussed in Sect. 3. In these regions, however, the land transport contribution to pollution is still limited according to our simulations. For the shipping sector, the strong reduction in aerosol sulfate concentrations in the near-future are expected to strongly reduce the climate impact from this sector. As we have shown in Sect. 4.2, however, reductions in sulfate are mostly compensated to some extent by increases in aerosol nitrate, which would explain the relatively small variations in the RF effect between 2000 and 2030. A significant exception is the RCP2.6 scenario, for which such compensation effect is less evident and a strong reduction in shipping-induced particle number concentration has been simulated (Fig. 9).

As it is clear in Fig. 11, our estimates of the climate impacts of transport sources are still affected by large uncertainties. As extensively discussed in R13, these can result from subgrid scale particle aging effects which cannot be resolved by the coarse resolution of global models, like the one which was adopted for this study. More research on this issue is needed, by means of dedicated measurements, plume models or highly resolving regional models.

\section{Conclusions}

We simulated the effects of the global land transport and shipping sectors emissions on atmospheric aerosol and climate in the year 2030 and analyze the changes with respect to 2000 , following the emission projections in the four RCPs (Moss et al., 2010).
The four RCPs project a general decrease in the globally integrated land transport emissions for all species, with only very few exceptions. In contrast, large regional differences occur, in particular, between the western countries (North America and European countries), which already implemented various mitigation strategies, and the Southeast Asian countries, where emissions of aerosol and aerosol precursor species from this sector are projected to continue growing until 2030 and beyond. The resulting effects in terms of aerosol surface-level mass concentrations mostly follow a similar regional trend, for both the land-transport-related pollution and the pollution related to other sources, the latter confirming the findings of previous studies (Takemura, 2012). The simulated land transport impact on particle number concentration is smaller than the effect on mass but is characterized by an analogous regional dependence.

The most striking feature of the future shipping emissions is the strong reduction in $\mathrm{SO}_{2}$ emissions projected by all scenarios and following the adoption of more stringent fuel sulfur content limits in this sector since 2010 (Buhaug et al., 2009). This leads to a clear decrease in shipping-induced aerosol sulfate concentration, especially in the Northern Hemisphere, where most of the shipping routes are located. This reduction correlates with an increase in aerosol nitrate, since the reduction in sulfate leads to an increase in free ammonia available for the formation of ammonium-nitrate. It is important to note that the shipping sector completely controls the changes in aerosol nitrate concentration between 2000 and 2030 over the oceans. The effects of shipping on particle number concentrations are even smaller than for land transport.

We recall that our assumption of year 2000 climate conditions for 2030 is a possible source of uncertainty. Aerosol composition and life cycle might experience significant 
changes due to changed climate conditions (see, e.g., Megaritis et al., 2013; Pozzer et al., 2014). Such changes and their specific implications for particle-induced climate effects of transport emissions shall be the subject of future investigations.

Both sectors are characterized by a significant reduction in the aerosol-induced RF effects, despite the growth in traffic volume. Land-transport-induced RF was found to decrease from $-80 \mathrm{~mW} \mathrm{~m}^{-2}$ in 2000 to about $-60 \mathrm{~mW} \mathrm{~m}^{-2}$ in 2030 . A strong decrease was simulated for shipping, from -181 in 2000 to $-53 \mathrm{~mW} \mathrm{~m}^{-2}$ in 2030 for the RCP2.6, in agreement with previous assessments (Righi et al., 2011), while for other scenarios the decrease is less pronounced.

The analysis of changes in aerosol distribution between 2000 and 2030 frequently revealed an anticorrelation of the air pollution impacts with the RCP ranking: the RCP scenarios with the most restrictive climate policies were often found to be characterized by a large impact in terms of short-lived pollutants, although exceptions exist. The RCPs cover a large range of future climate policies, but they have some limitations in terms of air pollution projections. They have been claimed to be excessively optimistic in terms of air pollution control, as they do not include, for example, a business-as-usual scenario. Air quality policy scenarios, such as EDGAR-CIRCE (Doering et al., 2009a, b) were considered in other studies (Pozzer et al., 2012), which however focused on the total pollution in different regions without differentiating between the different sectors, which was the major focus of the present study. Future studies on transport effects could also be based on such scenarios.

In the light of the discussion above, we shall stress that scenarios are projections of potential futures but not forecasts. The assumptions made when constructing the emission scenarios have a large impact on the simulation results. If the emission scenarios do not explore the full range of potential climate and air quality policies, we cannot expect that our simulation results will cover the full range of potential aerosol futures.

The present paper considered the land transport and the shipping sectors. In a follow-up work, we will perform an analogous analysis for the aviation sector, focusing on different regions and on the upper troposphere.

\section{The Supplement related to this article is available online at doi:10.5194/acp-15-633-2015-supplement.}

Acknowledgements. This study has been conducted in the framework of the DLR projects VEU and VEU-2, and of the EU-FP7 project REACT4C. The aerosol model MADE was originally developed by the University of Cologne, Germany (RIU/EURAD project). We are grateful to the whole MESSy team for the development of EMAC and in particular to Patrick Jöckel (DLR, Germany) for his help with the model setup. We thank Tina Jurkat (DLR, Germany) for her valuable comments on the manuscript draft, and Christopher Kaiser (DLR, Germany) for fruitful discussions.

The service charges for this open access publication have been covered by a Research Centre of the Helmholtz Association.

Edited by: A. Petzold

\section{References}

Abdul-Razzak, H. and Ghan, S. J.: A parameterization of aerosol activation, 2. Multiple aerosol types, J. Geophys. Res., 105, 68376844, doi:10.1029/1999JD901161, 2000.

Aquila, V., Hendricks, J., Lauer, A., Riemer, N., Vogel, H., Baumgardner, D., Minikin, A., Petzold, A., Schwarz, J. P., Spackman, J. R., Weinzierl, B., Righi, M., and Dall'Amico, M.: MADE-in: a new aerosol microphysics submodel for global simulation of insoluble particles and their mixing state, Geosci. Model Dev., 4, 325-355, doi:10.5194/gmd-4-325-2011, 2011.

Bellouin, N., Rae, J., Jones, A., Johnson, C., Haywood, J., and Boucher, O.: Aerosol forcing in the Climate Model Intercomparison Project (CMIP5) simulations by HadGEM2-ES and the role of ammonium nitrate, J. Geophys. Res., 116, 1-25, doi:10.1029/2011JD016074, 2011.

Buhaug, O., Corbett, J. J., Endresen, O., Eyring, V., Faber, J., Hanayama, S., Lee, D. S., Lee, D., Lindstad, H., Markowska, A. Z., Mjelde, A., Nelissen, D., Nilsen, J., Pålsson, C., Winebrake, J. J., Wu, W.-Q., and Yoshida, K.: Second IMO Greenhouse Gas Study 2009, Tech. rep., International Maritime Organization, London, UK, 2009.

Chalmers, N., Highwood, E. J., Hawkins, E., Sutton, R., and Wilcox, L. J.: Aerosol contribution to the rapid warming of near-term climate under RCP 2.6, Geophys. Res. Lett., 39, 2-7, doi:10.1029/2012GL052848, 2012.

Chow, J. C., Watson, J. G., Mauderly, J. L., Costa, D. L., Wyzga, R. E., Vedal, S., Hidy, G. M., Altshuler, S. L., Marrack, D., Heuss, J. M., Wolff, G. T., Pope III, C. A., and Dockery, D. W.: Health effects of fine particulate air pollution: lines that connect, J. Air Waste Manage., 56, 1368-1380, doi:10.1080/10473289.2006.10464545, 2006.

Clarke, L., Edmonds, J., Jacoby, H., Pitcher, H., Reilly, J., and Richels, R.: Scenarios of greenhouse gas emissions and atmospheric concentrations, Tech. rep., Department of Energy, Office of Biological \& Environmental Research, Washington DC, US, 2007.

Dentener, F., Kinne, S., Bond, T., Boucher, O., Cofala, J., Generoso, S., Ginoux, P., Gong, S., Hoelzemann, J. J., Ito, A., Marelli, L., Penner, J. E., Putaud, J.-P., Textor, C., Schulz, M., van der Werf, G. R., and Wilson, J.: Emissions of primary aerosol and precursor gases in the years 2000 and 1750 prescribed data-sets for AeroCom, Atmos. Chem. Phys., 6, 43214344, doi:10.5194/acp-6-4321-2006, 2006.

Doering, U., van Aardenne, J., Monni, S., Pagliari, V., Orlandini, L., and SanMartin, F.: CIRCE Report D8.1.2 - Evaluation Emission Database 1990-2005, Tech. rep., Project FP6, 6.3, No. 036961, 2009a. 
Doering, U., van Aardenne, J., Monni, S., Pagliari, V., Orlandini, L., and SanMartin, F.: CIRCE Report D8.1.3 - Update of Gridded Emission Inventories, Addition of Period 1990-1999 to 20002005 Dataset, Tech. rep., Project FP6, 6.3, No. 036961, 2009 b.

Eyring, V., Isaksen, I. S. A., Berntsen, T., Collins, W., Corbett, J. J., Endresen, O., Grainger, R. G., Moldanova, J., Schlager, H., and Stevenson, D. S.: Transport impacts on atmosphere and climate: shipping, Atmos. Environ., 44, 4735-4771, doi:10.1016/j.atmosenv.2009.04.059, 2010.

Fiore, A. M., Naik, V., Spracklen, D. V., Steiner, A., Unger, N., Prather, M., Bergmann, D., Cameron-Smith, P. J., Cionni, I., Collins, W. J., Dalsøren, S., Eyring, V., Folberth, G. A., Ginoux, P., Horowitz, L. W., Josse, B., Lamarque, J.-F., MacKenzie, I. A., Nagashima, T., O'Connor, F. M., Righi, M., Rumbold, S. T., Shindell, D. T., Skeie, R. B., Sudo, K., Szopa, S., Takemura, T., and Zeng, G.: Global air quality and climate., Chem. Soc. Rev., 41, 6663-6683, doi:10.1039/c2cs35095e, 2012.

Forster, P., Ramaswamy, V., Artaxo, P., Berntsen, T., Betts, R., Fahey, D. W., Haywood, J., Lean, J., Lowe, D. C., Myhre, G., Nganga, J., Prinn, R., Raga, G., Schulz, M., and Van Dorland, R.: Changes in atmospheric constituents and in radiative forcing, in: Climate Change 2007: The Physical Science Basis, Contribution of Working Group I to the Fourth Assessment Report of the Intergovernmental Panel on Climate Change, edited by: Solomon, S., Qin, D., Manning, M., Chen, Z., Marquis, M., Averyt, K. B., Tignor, M., and Miller, H. L., Cambridge University Press, Cambridge, UK and New York, NY, USA, 129-234, 2007.

Fujino, J., Nair, R., Kainuma, M., Masui, T., and Matsuoka, Y.: Multi-gas mitigation analysis on stabilization scenarios using aim global model, The Energy Journal, MultiGreenhouse Gas Mitigation and Climate Policy, 343-354, available at: http://EconPapers.repec.org/RePEc:aen:journl:2006se_ weyant-a17 (last access: 3 September 2014), 2006.

Jöckel, P., Tost, H., Pozzer, A., Brühl, C., Buchholz, J., Ganzeveld, L., Hoor, P., Kerkweg, A., Lawrence, M. G., Sander, R., Steil, B., Stiller, G., Tanarhte, M., Taraborrelli, D., van Aardenne, J., and Lelieveld, J.: The atmospheric chemistry general circulation model ECHAM5/MESSy1: consistent simulation of ozone from the surface to the mesosphere, Atmos. Chem. Phys., 6, 5067-5104, doi:10.5194/acp-6-5067-2006, 2006.

Kharol, S. K., Martin, R. V., Philip, S., Vogel, S., Henze, D. K., Chen, D., Wang, Y., Zhang, Q., and Heald, C. L.: Persistent sensitivity of Asian aerosol to emissions of nitrogen oxides, Geophys. Res. Lett., 40, 1021-1026, doi:10.1002/grl.50234, 2013.

Kirtman, B., Power, S., Adedoyin, J., Boer, G., Bojariu, R., Camilloni, I., Doblas-Reyes, F., Fiore, A., Kimoto, M., Meehl, G., Prather, M., Sarr, A. Schär, C., Sutton, R., van Oldenborgh, G. G. V., and Wang, H.: Near-term climate change: projections and predictability, in: Climate Change 2013: The Physical Science Basis, Contribution of Working Group I to the Fifth Assessment Report of the Intergovernmental Panel on Climate Change, edited by: Stocker, T., Qin, D., Plattner, G.-K., Tignor, M., Allen, S., Boschung, J., Nauels, A., Xia, Y., Bex, V., and Midgley, P., Cambridge University Press, Cambridge, UK and New York, NY, USA, 953-1028, 2013.

Kloster, S., Dentener, F., Feichter, J., Raes, F., Lohmann, U., Roeckner, E., and Fischer-Bruns, I.: A GCM study of future climate re- sponse to aerosol pollution reductions, Clim. Dynam., 34, 11771194, doi:10.1007/s00382-009-0573-0, 2009.

Lamarque, J.-F., Bond, T. C., Eyring, V., Granier, C., Heil, A., Klimont, Z., Lee, D., Liousse, C., Mieville, A., Owen, B., Schultz, M. G., Shindell, D., Smith, S. J., Stehfest, E., Van Aardenne, J., Cooper, O. R., Kainuma, M., Mahowald, N., McConnell, J. R., Naik, V., Riahi, K., and van Vuuren, D. P.: Historical (1850-2000) gridded anthropogenic and biomass burning emissions of reactive gases and aerosols: methodology and application, Atmos. Chem. Phys., 10, 7017-7039, doi:10.5194/acp10-7017-2010, 2010.

Lamarque, J.-F., Kyle, G. P., Meinshausen, M., Riahi, K., Smith, S. J., Vuuren, D., Conley, A. J., and Vitt, F.: Global and regional evolution of short-lived radiatively-active gases and aerosols in the Representative Concentration Pathways, Climatic Change, 109, 191-212, doi:10.1007/s10584-011-0155-0, 2011.

Lamarque, J.-F., Shindell, D. T., Josse, B., Young, P. J., Cionni, I., Eyring, V., Bergmann, D., Cameron-Smith, P., Collins, W. J., Doherty, R., Dalsoren, S., Faluvegi, G., Folberth, G., Ghan, S. J., Horowitz, L. W., Lee, Y. H., MacKenzie, I. A., Nagashima, T., Naik, V., Plummer, D., Righi, M., Rumbold, S. T., Schulz, M., Skeie, R. B., Stevenson, D. S., Strode, S., Sudo, K., Szopa, S., Voulgarakis, A., and Zeng, G.: The Atmospheric Chemistry and Climate Model Intercomparison Project (ACCMIP): overview and description of models, simulations and climate diagnostics, Geosci. Model Dev., 6, 179-206, doi:10.5194/gmd-6-179-2013, 2013.

Lauer, A., Hendricks, J., Ackermann, I., Schell, B., Hass, H., and Metzger, S.: Simulating aerosol microphysics with the ECHAM/MADE GCM - Part I: Model description and comparison with observations, Atmos. Chem. Phys., 5, 3251-3276, doi:10.5194/acp-5-3251-2005, 2005.

Lauer, A., Eyring, V., Hendricks, J., Jöckel, P., and Lohmann, U.: Global model simulations of the impact of ocean-going ships on aerosols, clouds, and the radiation budget, Atmos. Chem. Phys., 7, 5061-5079, doi:10.5194/acp-7-5061-2007, 2007.

Lauer, A., Eyring, V., Corbett, J. J., Wang, C., and Winebrake, J. J.: Assessment of near-future policy instruments for oceangoing shipping: impact on atmospheric aerosol burdens and the Earth's radiation budget, Environ. Sci. Technol., 43, 5592-5598, doi:10.1021/es900922h, 2009.

Lohmann, U.: Possible aerosol effects on ice clouds via contact nucleation, J. Atmos. Sci., 59, 647-656, doi:10.1175/15200469(2001)059<0647:PAEOIC>2.0.CO;2, 2002.

Lohmann, U. and Feichter, J.: Global indirect aerosol effects: a review, Atmos. Chem. Phys., 5, 715-737, doi:10.5194/acp-5-7152005, 2005.

Lohmann, U., Feichter, J., Chuang, C. C., and Penner, J. E.: Prediction of the number of cloud droplets in the ECHAM GCM, J. Geophys. Res., 104, 9169-9198, doi:10.1029/1999JD900046, 1999.

Masui, T., Matsumoto, K., Hijioka, Y., Kinoshita, T., Nozawa, T., Ishiwatari, S., Kato, E., Shukla, P., Yamagata, Y., and Kainuma, M.: An emission pathway for stabilization at $6 \mathrm{~W} \mathrm{~m}^{-2}$ radiative forcing, Climatic Change, 109, 59-76, doi:10.1007/s10584-011-0150-5, 2011.

Megaritis, A. G., Fountoukis, C., Charalampidis, P. E., Pilinis, C., and Pandis, S. N.: Response of fine particulate matter concentrations to changes of emissions and temperature in Europe, At- 
mos. Chem. Phys., 13, 3423-3443, doi:10.5194/acp-13-34232013, 2013

Moss, R. H., Edmonds, J. A., Hibbard, K. A., Manning, M. R., Rose, S. K., van Vuuren, D. P., Carter, T. R., Emori, S., Kainuma, M., Kram, T., Meehl, G. A., Mitchell, J. F. B., Nakicenovic, N., Riahi, K., Smith, S. J., Stouffer, R. J., Thomson, A. M., Weyant, J. P., and Wilbanks, T. J.: The next generation of scenarios for climate change research and assessment., Nature, 463, 747-56, doi:10.1038/nature08823, 2010.

Nakicenovic, N., Alcamo, J., Davis, G., de Vries, B., Fenhann, J., Gaffin, S., Gregory, K., Grübler, A., Jung, T. Y., Kram, T., Lebre La Rovere, E., Michaelis, L., Mori, S., Morita, T., Pepper, W., Pitcher, H., Price, L., Riahi, K., Roehrl, A., Rogner, H.-H., Sankovski, A., Schlesinger, M., Shukla, P., Smith, S., Swart, R., van Rooijen, S., Victor, N., and Dadi, Z.: Special Report on Emissions Scenarios: A Special Report of Working Group III of the Intergovernmental Panel on Climate Change, Cambridge University Press, Cambridge, UK, 2000.

Petzold, A., Hasselbach, J., Lauer, P., Baumann, R., Franke, K., Gurk, C., Schlager, H., and Weingartner, E.: Experimental studies on particle emissions from cruising ship, their characteristic properties, transformation and atmospheric lifetime in the marine boundary layer, Atmos. Chem. Phys., 8, 2387-2403, doi:10.5194/acp-8-2387-2008, 2008.

Pope, C. A. and Dockery, D. W.: Health effects of fine particulate air pollution: lines that connect, J. Air Waste Manage., 56, 709-742, doi:10.1080/10473289.2006.10464485, 2006.

Pozzer, A., Zimmermann, P., Doering, U.M., van Aardenne, J., Tost, H., Dentener, F., Janssens-Maenhout, G., and Lelieveld, J.: Effects of business-as-usual anthropogenic emissions on air quality, Atmos. Chem. Phys., 12, 6915-6937, doi:10.5194/acp-126915-2012, 2012.

Pozzer, A. de Meij, A., Yoon, J., Tost, H., Georgoulias, A. K., Astitha, M.: AOD trends during 2001-2010 from observations and model simulations. Atmos. Chem. Phys. Discuss., 14, 26619-26653, doi:10.5194/acpd-14-26619-201, 2014.

Pye, H. O. T., Liao, H., Wu, S., Mickley, L. J., Jacob, D. J., Henze, D. K., and Seinfeld, J. H.: Effect of changes in climate and emissions on future sulfate-nitrate-ammonium aerosol levels in the United States, J. Geophys. Res., 114, D01205, doi:10.1029/2008JD010701, 2009.

Riahi, K., Grübler, A., and Nakicenovic, N.: Scenarios of longterm socio-economic and environmental development under climate stabilization, Technol. Forecast. Soc., 74, 887-935, doi:10.1016/j.techfore.2006.05.026, 2007.

Riahi, K., Rao, S., Krey, V., Cho, C., Chirkov, V., Fischer, G., Kindermann, G., Nakicenovic, N., and Rafaj, P.: RCP 8.5 - a scenario of comparatively high greenhouse gas emissions, Climatic Change, 109, 33-57, doi:10.1007/s10584-011-0149-y, 2011.

Righi, M., Klinger, C., Eyring, V., Hendricks, J., Lauer, A., and Petzold, A.: Climate impact of biofuels in shipping: global model studies of the aerosol indirect effect, Environ. Sci. Technol., 45, 3519-3525, doi:10.1021/es1036157, 2011.

Righi, M., Hendricks, J., and Sausen, R.: The global impact of the transport sectors on atmospheric aerosol: simulations for year 2000 emissions, Atmos. Chem. Phys., 13, 9939-9970, doi:10.5194/acp-13-9939-2013, 2013.

Roeckner, E., Brokopf, E., Esch, M., Giorgetta, M. A., Hagema, S., and Kornblueh, L.: Sensitivity of simulated climate to horizon- tal and vertical resolution in the ECHAM5 atmosphere model, J. Climate, 19, 3771-3791, doi:10.1175/JCLI3824.1, 2006.

Rotstayn, L. D., Collier, M. A., Chrastansky, A., Jeffrey, S. J., and Luo, J.-J.: Projected effects of declining aerosols in RCP4.5: unmasking global warming?, Atmos. Chem. Phys., 13, 1088310905, doi:10.5194/acp-13-10883-2013, 2013.

Schulz, M., Textor, C., Kinne, S., Balkanski, Y., Bauer, S., Berntsen, T., Berglen, T., Boucher, O., Dentener, F., Guibert, S., Isaksen, I. S. A., Iversen, T., Koch, D., Kirkevåg, A., Liu, X., Montanaro, V., Myhre, G., Penner, J. E., Pitari, G., Reddy, S., Seland, Ø., Stier, P., and Takemura, T.: Radiative forcing by aerosols as derived from the AeroCom present-day and pre-industrial simulations, Atmos. Chem. Phys., 6, 5225-5246, doi:10.5194/acp-6-5225-2006, 2006.

Seinfeld, J. H. and Pandis, S. N.: Atmospheric Chemistry and Physics: From Air Pollution to Climate Change, John Wiley \& Sons, New York, US, 1998.

Smith, S. J. and Bond, T. C.: Two hundred fifty years of aerosols and climate: the end of the age of aerosols, Atmos. Chem. Phys., 14, 537-549, doi:10.5194/acp-14-537-2014, 2014.

Takemura, T.: Distributions and climate effects of atmospheric aerosols from the preindustrial era to 2100 along Representative Concentration Pathways (RCPs) simulated using the global aerosol model SPRINTARS, Atmos. Chem. Phys., 12, 1155511572, doi:10.5194/acp-12-11555-2012, 2012.

Taylor, K. E., Stouffer, R. J., and Meehl, G. A.: An overview of CMIP5 and the experiment design, B. Am. Meteorol. Soc., 93, 485-498, doi:10.1175/BAMS-D-11-00094.1, 2012.

Thomson, A. M., Calvin, K. V., Smith, S. J., Kyle, G. P., Volke, A., Patel, P., Delgado-Arias, S., Bond-Lamberty, B., Wise, M. A., Clarke, L. E., and Edmonds, J. A.: RCP4.5: a pathway for stabilization of radiative forcing by 2100, Climatic Change, 109, 77-94, doi:10.1007/s 10584-011-0151-4, 2011.

Uherek, E., Halenka, T., Borken-Kleefeld, J., Balkanski, Y., Berntsen, T., Borrego, C., Gauss, M., Hoor, P., Juda-Rezler, K., and Lelieveld, J.: Transport impacts on atmosphere and climate: land transport, Atmos. Environ., 44, 4772-4816, doi:10.1016/j.atmosenv.2010.01.002, 2010.

Unger, N., Zhao, Y., and Dang, H.: Mid-21st century chemical forcing of climate by the civil aviation sector, Geophys. Res. Lett., 40, 641-645, doi:10.1002/grl.50161, 2013.

van Vuuren, D. P., den Elzen, M. G. J., Lucas, P. L., Eickhout, B., Strengers, B. J., Ruijven, B., Wonink, S., and Houdt, R.: Stabilizing greenhouse gas concentrations at low levels: an assessment of reduction strategies and costs, Climatic Change, 81, 119-159, doi:10.1007/s10584-006-9172-9, 2007.

van Vuuren, D. P., Edmonds, J., Kainuma, M., Riahi, K., Thomson, A., Hibbard, K., Hurtt, G. C., Kram, T., Krey, V., Lamarque, J.-F., Masui, T., Meinshausen, M., Nakicenovic, N., Smith, S. J., and Rose, S. K.: The Representative Concentration Pathways: an overview, Climatic Change, 109, 5-31, doi:10.1007/s10584-011-0148-z, 2011a.

van Vuuren, D. P., Stehfest, E., Elzen, M., Kram, T., Vliet, J., Deetman, S., Isaac, M., Klein Goldewijk, K., Hof, A., Mendoza Beltran, A., Oostenrijk, R., and Ruijven, B.: RCP2.6: exploring the possibility to keep global mean temperature increase below $2{ }^{\circ} \mathrm{C}$, Climatic Change, 109, 95-116, doi:10.1007/s10584-011-0152-3, 2011b. 